\title{
Pyrolytic Organic-to-Inorganic Conversion of Precursors into AIN-A Review
}

\author{
Yusuke MORI and Yoshiyuki SUGAHARA
}

Department of Applied Chemistry, School of Science and Engineering, Waseda University, 3-4-1, Ohkubo, Shinjuku-ku, Tokyo

$169-8555$

\author{
有機-無機変換プロセスによる AIN の作製（総説） \\ 森＼cjkstart勇介・菅原義之 \\ 早稲田大学理工学部応用化学科, 169-8555 東京都新宿区大久保 3-4-1
}

\begin{abstract}
Pyrolytic "organic-to-inorganic" conversion of precursors (preceramic materials) into aluminum nitride (AIN) has been investigated for the past few decades. AIN precursors can be classified based on their starting aluminum compounds (organoaluminum compounds, inorganic compounds containing aluminum, and metallic aluminum). The preparation of various AIN precursors and their conversion mechanisms during pyrolysis are reviewed.

[Received February 27, 2006; Accepted April 19, 2006]
\end{abstract}

Key-words : Precursors, Pyrolytic organic-to-inorganic conversion, Aluminum nitride, Non-oxide ceramics, Ceramic-based composites

\section{Introduction}

$\mathbf{P}$ YROLYTIC organic-to-inorganic conversion of precursors (preceramic materials), which are typically organometallic and/or inorganic polymers possessing metal-nitrogen and/or metal-carbon backbones, is a novel route to obtaining non-oxide materials (Fig. 1). ${ }^{1)-5)}$ If precursors are liquid, fusible at relatively low temperatures or soluble in common organic solvents, this process can offer fabrication routes to ceramics and ceramic-based composites with desirable shapes, including coatings and fibers. Additional potential applications for this route include sintering aids and binders (Fig. 2). ${ }^{3)-5)}$ These applications are essentially unattainable by a conventional powder-processing route. ${ }^{4}$ This route can also offer the preparation of ceramic materials possessing multiple metals (and semimetals), since precursors can exhibit atomic-scale homogeneity, leading to formation of highly homogeneous amorphous materials and ceramic composites

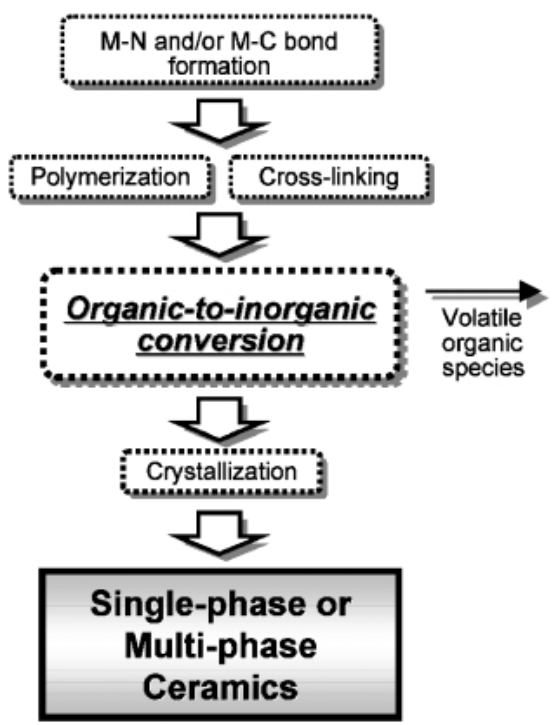

Fig. 1. Flow diagram for the preparation of ceramics via pyrolytic organic-to-inorganic conversion. with better microstructures upon pyrolysis.

$\mathrm{AlN}^{6)-16)}$ has been considered as one of the attractive nitrogen ceramics with various properties, including high thermal conductivity, high electrical resistively, low dielectric constant, high thermal and chemical stability and a low thermal expansion coefficient very close to that of silicon. In consideration of these intrinsic properties, AlN is expected to be a promising ceramic material for electronic and optoelectronic applications, ${ }^{7,(17)-20)}$ such as heat sinks, hybrid substrates in integrated circuits, high power/frequency electronic devices and surface acoustic wave (SAW) devices. AlN powders have generally been prepared by carbothermal reduction of an alumina-carbon mixture, ${ }^{21-25)}$ polymeric precursors containing an aluminum-oxygen network and a carbon source ${ }^{26), 27)}$ and intercalation compounds ${ }^{28)-30)}$ under a nitrogen atmosphere, and by direct and floating nitridation. ${ }^{31)-33)}$ In addition, AlN films have been prepared by a chemical vapor deposition (CVD) process. ${ }^{34)-38)}$

As a novel route to obtaining AlN, pyrolytic conversion of precursors has been investigated for past few decades. We review here the preparation of various AlN precursors based on the starting materials for aluminum source: from organoaluminum compounds and inorganic compounds containing aluminum [such as $\mathrm{AlH}_{3}$ (and its adduct), $\mathrm{LiAlH}_{4}$, aluminum halides], and on their pyrolysis processes, as well as on

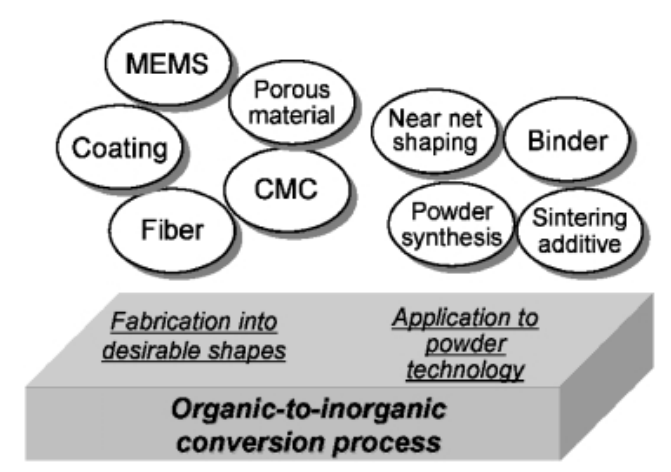

Fig. 2. Preparation of ceramic materials by precursor processing. 
the pyrolytic conversion of precursors for other non-oxide ceramics and their composites. The preparation of AIN via an electrochemical technique using metallic aluminum is also described in this review.

\section{Pyrolytic organic-to-inorganic conversion of precursors} into non-oxide ceramics (and ceramic-based composites)

\subsection{Design of precursors ${ }^{1,3), 5}$}

Design of precursors is extremely important for obtaining useful precursors since successful applications of the pyrolytic organic-to-inorganic conversion process depend strongly on the properties and structure of precursors.

As mentioned above, to be useful, a precursor should usually be a liquid, or if a solid, it should be soluble in common organic solvents or fusible at relatively low temperatures in order to permit desired applications (such as fabrication of ceramics with desirable shapes). In addition, volatile products that evolve during pyrolysis should preferably be nonhazardous and nontoxic. A useful precursor should exhibit a high ceramic yield, moreover, leading to less shrinkage and a reduction in destructive effects caused by evolved gaseous species.

Many linear polymeric precursors, even when compounds with high molecular masses, exhibit negligible ceramic yields because of the generation and volatilization of low molecular mass compounds (e.g., cyclic species). Precursors exhibiting high ceramic yields should therefore possess cross-linked structures, but highly cross-linked structures generally exhibit very low solubility in common organic solvents.

In order to prepare a soluble precursor with a relatively high ceramic yield, two following strategies have been proposed. One is the introduction of bulky organic groups into a precursor, which can lead to formation of a soluble precursor, since the introduction of these groups can suppress the formation of a highly cross-linked structure. Materials obtained by pyrolysis of such precursors could contain undesirable carbon in the form of free carbon as well as carbides, however, which could lead to degradation of its potential, in particular, for the preparation of nitrides. Thus, the carbon content of soluble precursors (especially precursors for nitrides) should be as low as possible.

The other strategy is the use of oligomers, ${ }^{39)}$ or even monomers, ${ }^{40)}$ possessing reactive groups. Oligomers and monomers are generally soluble in common organic solvents, but they exhibit low ceramic yields because of their volatilization during pyrolysis. If cross-linking reactions occur before their volatilization, however, the ceramic yields can be increased. For the facile occurrence of cross-linking reactions, it is desirable for appropriate reactive (or potentially reactive) substituent groups (e.g., unsaturated organic groups or reactive bonds such as $\mathrm{SiH}, \mathrm{NH}, \mathrm{BH}$ and $\mathrm{AlH}$ ) to be introduced into precursors. Thus, design of precursor is highly important for these strategies.

\subsection{Precursors for non-oxide ceramics}

The preparation of non-oxide ceramics (nitride and carbide) and their composites through pyrolysis of precursors was initially developed by Verbeek, Winter, and Yajima and co-workers in 1970's. ${ }^{41)-45)}$ Yajima and co-workers prepared silicon carbide ( $\mathrm{SiC}$ ) by pyrolysis of poly (carbosilane) (PCS) obtained from poly (dimethylsilane), which was synthesized by alkali-metal-promoted dehalocoupling of chlorosilanes (Wurtz coupling). ${ }^{43)-48)}$ The conversion of poly (silane) (PS) into PCS, often called the Kumada rearrangement, ${ }^{49)-51 \text { ) }}$ occurs at $\sim 470^{\circ} \mathrm{C}$ via a radical mechanism. Poly (carbosilane) with a $50-55 \%$ yield was obtained through this route. To improve the synthesis (to increase the PCS yield and to lower the reaction temperature and time), PCS was prepared using Lewis acid catalysts (such as diphenylborosiloxane polymer). 52),53) The Yajima route has been employed for the commercial fabrication of such $\mathrm{SiC}$ fibers as "Nicalon (or HiNicalon)" fiber $\left(\mathrm{SiC}_{x} \mathrm{O}_{y} \text {, Nippon Carbon Co., Ltd. }\right)^{54)}$ and "Tyrano" fiber $\left(\mathrm{SiTi}_{x} \mathrm{C}_{y} \mathrm{O}_{z}\right.$, Ube Industries, Ltd.). ${ }^{55)}$

Numerous other PSs and PCSs have been widely prepared as $\mathrm{SiC}$ precursors via various synthetic methods. ${ }^{56)-59)}$ The preparation of PCSs was also advanced by ring-opening polymerization of various derivatives of 1,3-disilacyclobutane. ${ }^{60)-63)} \mathrm{Poly}$ (silapropylene)s $\left[\mathrm{Me}(\mathrm{H}) \mathrm{SiCH}_{2}\right]_{n}$ (or poly $[($ methylchlorosilylene $)$ methylene $\left.] \quad\left[\mathrm{Me}(\mathrm{Cl}) \mathrm{SiCH}_{2}\right]_{n}\right)$ via $\mathrm{H}_{2} \mathrm{PtCl}_{6}$-catalyzed ring-opening polymerization gave $\mathrm{SiC}$ with quite low ceramic yields due to their linear structures, and cross-linked polymers were consequently synthesized by further treatment. ${ }^{64)}$ PCSs were also prepared by Pt-catalyzed hydrosilylation of vinyldichlorosilane $\mathrm{SiH}\left(\mathrm{CH}_{2}=\mathrm{CH}\right)$ $\mathrm{Cl} .{ }^{65)}{ }^{-67)}$ The increase in the introduction of vinyl groups led to high ceramic yields but gave rise to a higher carbon content in the resulting materials. Schilling et al. ${ }^{68), 69)}$ revealed that $\mathrm{SiC}$ was obtained by pyrolysis of PCSs, which were synthesized via reactions of vinylmethyldichlorosilane with other chlorosilane monomers $\left(\mathrm{Me}_{3} \mathrm{SiCl}\right.$ and/or $\left.\mathrm{Me}_{2} \mathrm{SiCl}_{2}\right)$.

Poly (dimethylsilane), described above, is a polymer that is insoluble and infusible, which is a large drawback as a precursor. West et al. prepared poly (silastylene)s possessing phenyl groups via sodium-promoted Wurtz coupling between $\mathrm{PhMeSiCl}_{2}$ and $\mathrm{Me}_{2} \mathrm{SiCl}_{2}$, leading to enhancement of their solubility in common organic solvents. ${ }^{70)-72)}$ Poly (methylsilane)s (PMS) prepared by dehalocoupling of dichloromethylsilane ${ }^{68), 69), 73), 74)}$ exhibit quite low ceramic yields (15-20 mass $\%$ ), and the resulting materials contained a 25 mass $\%$ excess of metallic silicon that crystallized at higher temperatures. $^{73)}$ To achieve increases in ceramic yield and carbon content, modification of PMS via Pt-catalyzed hydrosilylation with organic or organosilicon compounds has been conducted. ${ }^{74)}$ Other approaches to increasing the ceramic yield of PMS have utilized various catalysts, such as transition metals $^{75), 76)}$ and boron compounds. ${ }^{77)-79)}$

The preparation of silicon nitride $\left(\mathrm{Si}_{3} \mathrm{~N}_{4}\right)$ via pyrolytic conversion of poly (silazane)s, which typically possess an $\mathrm{Si}-\mathrm{N}$ backbone, has been extensively investigated. ${ }^{57), 80)}$ An oily poly (silazane) with the proposed formula of $\left[\left(\mathrm{H}_{2} \mathrm{SiNH}\right)_{0.42}\right.$ $\left.\left(\mathrm{H}_{2} \mathrm{Si}_{1.5} \mathrm{~N}\right)_{0.58}\right]_{n}$ was prepared by ammonolysis of dichlorosilane $\left(\mathrm{H}_{2} \mathrm{SiCl}_{2}\right)$ in polar solvents. ${ }^{81), 82)}$ Pyrolysis of the oily polysilazane led to the formation of a brown solid, which contained $\alpha-\mathrm{Si}_{3} \mathrm{~N}_{4}, \beta-\mathrm{Si}_{3} \mathrm{~N}_{4}$ and a trace of metallic silicon. The cyclic silazane oligomers $\left(\mathrm{R}^{1} \mathrm{R}^{2} \mathrm{SiNR}^{3}\right)_{n}$ (mainly $\left.n=3-5\right)$ were generally prepared via ammonolysis of organodichlorosilanes. ${ }^{57), 80)}$ Since the average molecular masses of these compounds were low, they exhibited low ceramic yields.

As poly (silazane) $s$ with higher ceramic yields, methylhydridpolysilazanes were prepared via $\mathrm{KH}$ catalyzed dehydrocondensation of methylcyclosilazane $[\mathrm{Me}(\mathrm{H}) \mathrm{SiNH}]_{n}{ }^{82)}$,83) The ceramic yields of these poly(silazane)s were relatively high (80-85 mass\%) due to their cross-linked structures. The resulting material consisted of $\mathrm{Si}_{3} \mathrm{~N}_{4}, \mathrm{SiC}$ and a trace of free carbon. Blum et al. prepared cross-linked poly(silazane)s, moreover, via transition-metal-catalyzed dehydrocondensation. ${ }^{84), 85)}$

The thermal cross-linking reactions of various cyclic silazane oligomers $\left(\mathrm{R}^{1} \mathrm{R}^{2} \mathrm{SiNR}^{3}\right)_{n}$ and the pyrolysis processes of the resultant cross-linked polymers have been investigated. ${ }^{39), 85)-88)}$ The ceramic yields and chemical compositions of 
the resulting materials were heavily dependent on the organic substituents and the pyrolysis atmospheres. The oligomers possessing $\mathrm{SiH}$ and $\mathrm{Si}-\mathrm{CH}=\mathrm{CH}_{2}$ or $\mathrm{NH}$ groups were easily converted into cross-linked structures at relatively low temperatures, leading to high-yield conversion into the resulting materials. The presence of the $\mathrm{Si}-\mathrm{CH}_{3}$ groups [not the Si$\mathrm{C}_{x} \mathrm{H}_{2 x+1}$ groups $(x \geq 2)$ or Si-phenyl groups] in the oligomers is favorable for the formation of $\mathrm{Si}-\mathrm{CH}_{2}-\mathrm{Si}$ intermediate links, which can lead to $\mathrm{SiC}$ formation in $\mathrm{Si}_{3} \mathrm{~N}_{4}$ with further pyrolysis. Pyrolysis under an argon atmosphere gave ceramics with high yields and high carbon content, whereas pyrolysis under an $\mathrm{NH}_{3}$ atmosphere resulted in the formation of pure $\mathrm{Si}_{3} \mathrm{~N}_{4}$ due to nucleophilic and/or free-radical substitution by $\mathrm{NH}_{3}$.

Isoda and co-workers prepared a novel soluble poly (silazane) (perhydropolysilazane) by ammonolysis of a dichlorosilane-pyridine complex. ${ }^{89)}$ Continuous stoichiometric $\mathrm{Si}_{3} \mathrm{~N}_{4}$ fiber was fabricated by the pyrolysis of perhydropolysilazane. ${ }^{90)}$ This high-purity silicon nitride fiber possessed high strength, a modulus of elasticity, and thermal stability, which are properties suitable for reinforcing plastics, metals, glasses, and even ceramics.

As precursors for boron nitride $(\mathrm{BN})$, Sneddon and coworkers prepared poly (borazylene) $\left(\mathrm{B}_{3} \mathrm{~N}_{3} \mathrm{H}_{4}\right)_{n}$ obtained by dehydrocondensation of borazine $\left(\mathrm{B}_{3} \mathrm{~N}_{3} \mathrm{H}_{6}\right)$ at moderate temperatures. ${ }^{91)-93)}$ Pyrolysis of poly (borazylene) at $1200^{\circ} \mathrm{C}$ led to the formation of white $\mathrm{BN}$ powders with high yields $(>84$ mass \%). High-quality BN thin films on silicon were produced by spin-coating solutions of poly(borazylene)..$^{94)}$ Since the cross-linking reactions occurred at low temperatures, ${ }^{93)}$ however, it was difficult to adapt poly (borazylene) to applications requiring melt-processing. To overcome this drawback, new polymeric precursors to $\mathrm{BN}$ ceramics were prepared through reactions of poly (borazylene) with diethylamine (DEA), dipentylamine (DPA), and hexamethyldisilazane (HMD) . ${ }^{95)-97)}$ The DPA-poly (borazylene) polymers led to the successful preparation of continuous polymer fibers (30-40 $\mu \mathrm{m}$ in diameter) with a melt-spun technique. Pyrolysis of the polymer fibers under ammonia gave high-quality $\mathrm{BN}$ ceramic fibers $(30 \mu \mathrm{m}$ in diameter $) .{ }^{95)}$

Paine and Narula prepared poly(borazinylamine) gels obtained by a reaction between hexamethyldisilazane and Btrichloroborazine. ${ }^{98), 99)}$ Crystalline graphite-like BN ( $h$-BN) was obtained by pyrolysis of poly(borazinylamine) gels at $1200^{\circ} \mathrm{C}$. The formation of coatings and fibers was also achieved using these gels. Sneddon and co-workers investigated the preparation of B-vinylborazine via transition metalcatalyzed addition between borazine and acetylene and its polymerization (by thermal treatment ${ }^{100), 101)}$ and free-radical initiation with AIBN $^{102)}$ ). Thermal polymerization of B-vinylborazine at $120^{\circ} \mathrm{C}$ led to the formation of an insoluble, rubbery polymer possessing a carbon-carbon backbone. A soluble polymer was moreover prepared by thermal polymerization of B-vinylborazine and borazine. In this case, borazine may play a role as a chain terminating reagent to cap the ends of the carbon-carbon backbone in the vinyl polymer. Pyrolysis of these polymers resulted in the formation of ceramic materials with $\mathrm{B} / \mathrm{N}$ ratios of $\sim 1.0$.

2.3 Precursors for non-oxide ceramic-based composites

Ceramic-based composites have been recognized as attractive materials, since they provide a unique combination of characteristics and therefore offer tailoring and improvement of properties. ${ }^{103)}$ Walker et al. first reported the preparation of non-oxide ceramic-based composites via pyrolytic organicto-inorganic conversion. ${ }^{104)}$ The preparation of precursors for ceramic-based composites has since been extensively investigated, and the following three approaches have been proposed. ${ }^{105)}$ In the first method, inorganic and/or organometallic precursors have been combined with reactive fillers such as pure, fine-grade metals and ceramics (as a second ceramic phase). This approach can provide improvement of their ceramic yields and suppress the evolution of gaseous species, with a resulting absence of change from the elemental compositions of the precursors to those of the resulting materials, while overcoming the intrinsic problem of shrinkage and porosity formation. In addition, when a metal powder is utilized and dispersed homogeneously, this second ceramic phase is also expected to be highly dispersed.

A second approach to the preparation of precursors for ceramic-based composites has employed the liquid-phase mixing of two (or more than two) single-component precursors. This approach makes it easy to achieve molecular-level homogeneity in the precursors.

A third approach is the preparation of single-source precursors. Single-source precursors typically possess heterogeneous $\mathrm{M}-\mathrm{N}-\mathrm{M}^{\prime}$ and/or $\mathrm{M}-\mathrm{C}-\mathrm{M}^{\prime}$ linkages, leading to atomic-level homogeneity of the elemental precursor compositions. Singlesource precursors have also been prepared by tailoring singlecomponent polymeric precursors with monomeric or oligomeric species.

As concerns the approach of blending of precursors with powder, the $\mathrm{Si}-\mathrm{M}-\mathrm{C}-\mathrm{N}-\mathrm{O}(\mathrm{M}=\mathrm{Al}, \mathrm{Ti}, \mathrm{Cr}, \mathrm{V}, \mathrm{Zr}, \mathrm{Nb}, \mathrm{Mo}$, Ta, W, Si, B, $\mathrm{CrSi}_{2}, \mathrm{MoSi}_{2}$, etc.) composites were prepared from Si-based precursors such as poly(carbosilane)s, poly (silazane)s and poly(siloxane)s incorporating reactive filler particles. ${ }^{106)}$,107) $\mathrm{Su}$ et al. revealed that combining BN precursors with $\mathrm{Ti}$ powders led to the formation of $\mathrm{TiB}_{2}$ and $\mathrm{TiN}$ by pyrolysis at $1450^{\circ} \mathrm{C} .^{108)}$

As concerns the approach employing a blended precursor technique, ${ }^{109)}$ Interrante et al. utilized combinations of an AlN precursor $\left(\mathrm{Et}_{2} \mathrm{AlNH}_{2}\right)_{3}$ with $\mathrm{SiC}$ precursors, vinylic poly (silane), methylhydridopolysilanes, or hydridopolysilane precursors and revealed that their pyrolysis led to the formation of nanocrystalline ceramic-based composites or solid solutions, such as $\mathrm{SiC} / \mathrm{AlN}$ and $\mathrm{Si}_{3} \mathrm{~N}_{4} / \mathrm{AlN} .^{110)-112)}$ A higher homogeneity could be achieved by rapid pyrolysis (the socalled "hot drop" approach) than by slow pyrolysis. $\mathrm{Si}_{3} \mathrm{~N}_{4} / \mathrm{BN}$ composites were also prepared by pyrolysis of blended precursors obtained from vinylic poly (silane)s and poly (borazinylamine). ${ }^{112), 113)}$ Moreas et al. prepared the blended precursors from allylhydoridpolycarbosilane and poly (borazylene)s, leading to the formation of $\mathrm{SiC} / \mathrm{BN}$ composites by pyrolysis. ${ }^{114)}$

Single-source precursors have mainly been prepared by ammonolysis or aminolysis of single-source monomeric species possessing heterogeneous linkages. Baldus et al. prepared highly cross-linked borosilicon imides by ammonolysis or aminolysis of $\mathrm{Cl}_{3} \mathrm{Si}-\mathrm{NH}-\mathrm{BCl}_{2}$ obtained from $\mathrm{Cl}_{3} \mathrm{Si}-\mathrm{NH}-$ $\mathrm{Si}\left(\mathrm{CH}_{3}\right)_{2}$ and $\mathrm{BCl}_{3}$, leading to the formation of amorphous $\mathrm{Si}-\mathrm{B}-\mathrm{N}$ and $\mathrm{Si}-\mathrm{B}-\mathrm{C}-\mathrm{N}$ materials by pyrolysis. ${ }^{115)}$ Janik et al. and Paciorek et al. prepared single-source precursors for $\mathrm{Al}-\mathrm{Si}-\mathrm{N}-\mathrm{C}$ composites through reactions of $\left(\mathrm{Me}_{3} \mathrm{Si}\right)_{3} \mathrm{Al}$. $\mathrm{OEt}_{2}$ or $\left[\left(\mathrm{SiMe}_{3}\right)_{2} \mathrm{~N}\right]_{3} \mathrm{Al}$ with ammonia in various molar ratios. ${ }^{116)-118)}$ As another approach to preparation of singlesource precursors from monomeric species, Loffelholz et al. reported the preparation of precursors for $\mathrm{Si}-\mathrm{B}-\mathrm{N}$ and $\mathrm{Si}-\mathrm{Al}-\mathrm{N}$ composite by dehydrocondensation of two singlecomponent monomers $\left[\mathrm{Si}\left(\mathrm{NHCH}_{3}\right)_{4}\right.$ and Lewis-base adducts of alane or borane]. ${ }^{119)}$ Single-source precursors have also been prepared by the modification of single-component polymeric precursors. Monomeric or oligomeric compounds were 
bound to polymeric precursors as pendant side-chain groups via dehydrocondensation, deamination, dealkylation or dealcoholization. As a typical example, Hapke and Ziegler prepared Si-Ti-C-N composites by pyrolysis of poly (titanasilazane) obtained via deamination of poly(silazane) with $\mathrm{Ti}\left(\mathrm{NMe}_{2}\right)_{4} \cdot{ }^{120)}$ The chemical modification of Si-based polymers such as oligosilazanes, poly (silazane) s and poly (carbosilane) $s$ has also been extensively investigated. ${ }^{110), 121)-134)}$

Among various ceramic composites, $\mathrm{Si}-\mathrm{B}-\mathrm{C}-\mathrm{N}$ composites derived from polymeric precursors have lately drawn considerable attention because of their significant potentials (stemming from such characteristics as high thermal stability and oxidation resistance, high crystallization temperature and high ceramic yields). Sneddon and co-workers prepared $\mathrm{Si}-\mathrm{B}-\mathrm{C}-\mathrm{N}$ precursors through reactions between boron compounds (borazine or the monofunctional boranes) and silazanes [tris (trimethylsilylamino) silane, 1,1,3,3,5,5-hexamethylcyclotrisilazane or poly (silazane) ].97),135)-137) Riedel et al. revealed that silicoboron carbonitride was obtained by pyrolysis of poly (borosilazane), which was prepared by ammonolysis of MeSi $\left.\left(\mathrm{Cl}_{2}\right)-\mathrm{CH}_{2} \mathrm{CH}_{2}-\mathrm{BR}_{2} \cdot{ }^{138}\right)$ This composite was thermally stable up to $2000^{\circ} \mathrm{C}$, suggesting that boron was effective in stabilizing the $\mathrm{Si}-\mathrm{C}-\mathrm{N}$ amorphous materials. Numerous studies on pyrolytic conversion of $\mathrm{Si}-\mathrm{B}-\mathrm{C}-\mathrm{N}$ precursors have been summarized in recent reviews. ${ }^{80,97), 139), 140)}$

2.4 Investigation of pyrolytic organic-to-inorganic conversion process

Investigation of the pyrolytic process, as well as characterization of the precursors and the resulting materials, is highly important for designing precursors with high ceramic yields and controlling the chemical compositions of the resulting materials. Information concerning pyrolytic behavior can be obtained by using thermogravimetry (TG), especially thermogravimetry associated with continuous mass spectrometry (TG-MS) ${ }^{87)}$ The gaseous species evolved during pyrolysis can be analyzed using gas chromatograph-mass spectrometry (GC-MS) and gas chromatograph-infrared (GC-IR) spectroscopy. ${ }^{141)}$ GC-MS can provide direct identification of the evolved gaseous species. The functional groups of the evolved gaseous species can be determined by means of GC-IR. In addition, investigation of the pyrolytic process can be conducted using IR and solid-state magnetic nuclear resonance (NMR) spectroscopy, ${ }^{136}$ ) which can determine the surrounding environments of elements as well as the functional groups presented in intermediate solids during pyrolysis. The pyrolytic organic-to-inorganic conversion processes, which possibly include the dissociation (bond scission) reactions and crosslinking reactions (e.g., addition reaction, condensation reaction, etc.), can therefore be clarified by the combination of these analyses.

\section{AIN precursors}

Practical investigations of pyrolytic organic-to-inorganic conversion into AlN were first reported in 1986. ${ }^{16), 142)}$ Since then, the preparation of AlN from organometallic/inorganic precursors has been extensively investigated. Main interest was initially focused on the fabrication of AlN (powder, film and fiber). The mechanism of conversion into AlN during pyrolysis and the preparation of precursors for AlN-based composites have recently been pursued. Besides development of AlN precursors, precursors for AlN-based composites have been prepared through the use of oligomeric AlN precursors as building blocks as well as of single-source precursors, as shown by the following typical examples. Interrante et al. prepared a viscous Al-B-N precursor from $(\mathrm{EtNH})_{3} \mathrm{~B}$ and
$\left(\mathrm{Et}_{2} \mathrm{AlNH}_{2}\right)_{3}$, leading to the formation of homogeneously dispersed AlN particles in a $t$-BN matrix. ${ }^{143)}$ They also prepared $\mathrm{SiC} / \mathrm{AlN}, \mathrm{Si}_{3} \mathrm{~N}_{4} / \mathrm{AlN}$ composites using $\left.\left(\mathrm{Et}_{2} \mathrm{AlNH}_{2}\right)_{3} \cdot{ }^{109)-111}\right)$ $\mathrm{Al}-\mathrm{Si}-\mathrm{N}-\mathrm{C}^{144)}{ }^{145)}$ and $\mathrm{Ti}-\mathrm{Al}-\mathrm{N}^{146)}$ composites were obtained by pyrolysis of precursors prepared by the combination of $\left(\mathrm{HAlN}{ }^{i} \mathrm{Pr}\right)_{n}$ with $[\mathrm{Me}(\mathrm{H}) \mathrm{SiNH}]_{m}$ or an aminolysis product of $\mathrm{Ti}\left(\mathrm{NMe}_{2}\right)_{4}$, respectively.

This section describes the preparation of AlN precursors and their pyrolytic organic-to-inorganic conversion. Here we classify AlN precursors into the following three categories based on the starting compounds:

1) AlN precursors from organoaluminum compounds

2) AlN precursors from inorganic compounds containing aluminum [such as $\mathrm{AlH}_{3}$ (and its adduct), $\mathrm{LiAlH}_{4}$ and aluminum halides]

3) Electrochemical preparation of AIN (starting from metallic aluminum)

The CVD process related to organometallic compounds possessing an Al-N backbone is described as well.

3.1 AIN precursors from organoaluminum compounds

Wiberg suggested that products prepared by reactions between $\mathrm{Me}_{3} \mathrm{Al}$ and ammonia were converted into AlN upon pyrolysis in 1948. ${ }^{147)}$ Further development of this trialkylaluminum chemistry was advanced by Interrante and coworkers. ${ }^{16), 148)-151)}$ The adducts $\mathrm{R}_{3} \mathrm{Al} \cdot \mathrm{NH}_{3}$ from $\mathrm{R}_{3} \mathrm{Al}$ and ammonia were thermally converted into $\mathrm{R}_{2} \mathrm{AlNH}_{2}$ with a loss of alkane $(\mathrm{RH})$.

$$
\begin{aligned}
& \mathrm{R}_{3} \mathrm{Al}+\mathrm{NH}_{3} \longrightarrow \mathrm{R}_{3} \mathrm{Al} \cdot \mathrm{NH}_{3} \\
& \mathrm{R}_{3} \mathrm{Al} \cdot \mathrm{NH}_{3} \longrightarrow \mathrm{R}_{2} \mathrm{AlNH} \mathrm{NH}_{2}+\mathrm{RH}
\end{aligned}
$$

The thermal decomposition mechanism of the adduct $\mathrm{Me}_{3} \mathrm{Al} \cdot \mathrm{NH}_{3}$ in solution are shown in Fig. 3. ${ }^{148), 149)}$ The structure of the dialkylaluminum amide $\mathrm{R}_{2} \mathrm{AlNH}_{2}$ was typically cyclic trimer $\left.\left(\mathrm{R}_{2} \mathrm{AlNH}\right)_{3}\right)_{3}$ with a six-membered $(\mathrm{AlN})_{3}$ ring in a crystalline state, but equilibrium between the trimer and dimer was present in solutions. The trimer/dimer ratio decreased with increase in the sizes of the organic substituents on aluminum, and $\mathrm{NH}_{3}$ strongly catalyzed this trimer-dimer conversion. (Fig. 4) ${ }^{148), 150)}$ Pyrolytic conversion into the alkylaluminum imide polymer $(\mathrm{RAlNH})_{n}$ from $\left(\mathrm{R}_{2} \mathrm{AlNH}_{2}\right)_{3}$ was proposed as shown in Fig. 5. ${ }^{151)}$ The heterolytic cleavage of an $\mathrm{Al}-\mathrm{N}$ bond in an $(\mathrm{AlN})_{3}$ ring and the subsequent attack of a nitrogen terminal $(=\mathrm{N}$ : $)$, which was generated by this

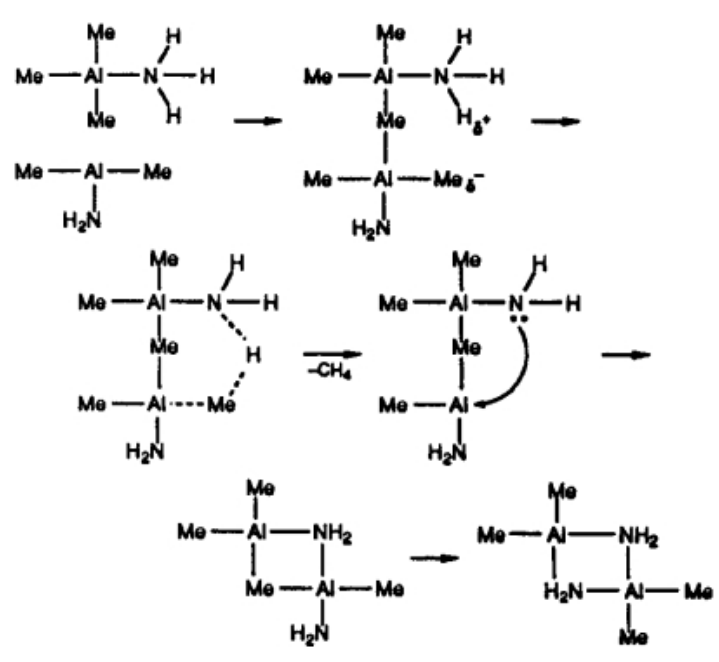

Fig. 3. Proposed mechanism for the thermal decomposition of $\mathrm{Me}_{3} \mathrm{Al} \cdot \mathrm{NH}_{3} \cdot{ }^{148)}$ 
(a) Uncatalyzed

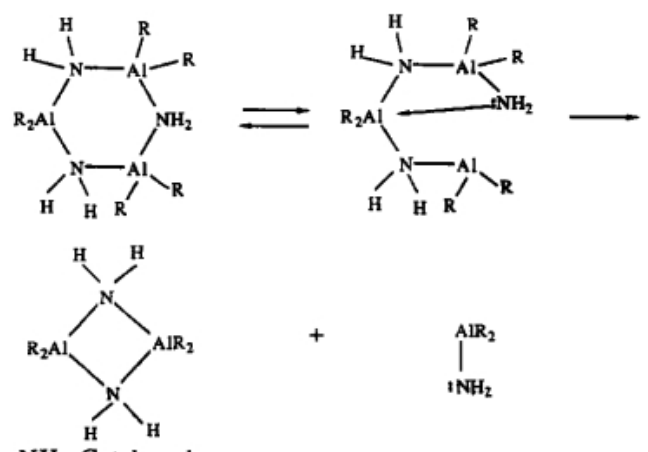

(b) $\mathrm{NH}_{3}$-Catalyzed
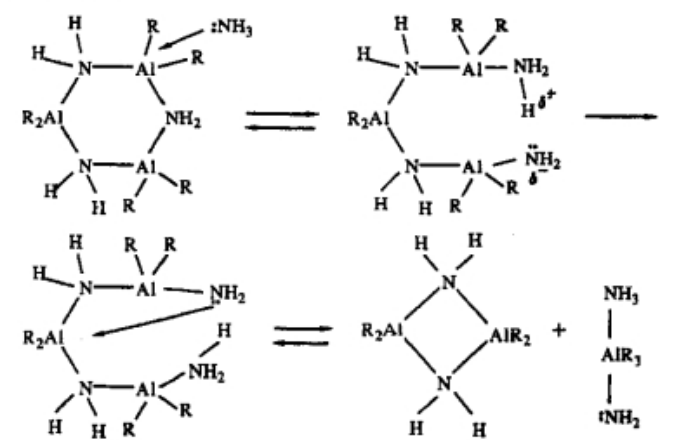

Fig. 4. Proposed mechanism for dimer-trimer equilibrium. ${ }^{148)}$

cleavage, on another $(\mathrm{AIN})_{3}$ ring led to conversion into the $(\mathrm{RAlNH})_{n}$ with a loss of alkane $(\mathrm{RH})$. The formation of AlN from $(\mathrm{RAlNH})_{n}$ occurred via radical processes. They also demonstrated that the pyrolytic conversion of $\left(\mathrm{Me}_{2} \mathrm{AlNH}_{2}\right)_{3}$ to AlN occurred in 28 mass $\%$ up to $1000^{\circ} \mathrm{C}$.

A soluble organoaluminum polymer $\left[(\mathrm{EtAlNH})_{n}\left(\mathrm{Et}_{2}\right.\right.$ $\left.\left.\mathrm{AlNH}_{2}\right)_{m} \mathrm{AlEt}_{3}\right]$ was prepared from $\left(\mathrm{Et}_{2} \mathrm{AlNH}_{2}\right)_{3}$ and $\mathrm{AlEt}_{3}$. (Scheme 1) ${ }^{152)-155)}$ Although the thermal decomposition of $\left(\mathrm{Et}_{2} \mathrm{AlNH}_{2}\right)_{3}$ resulted in the formation of the infusible polymer $(\mathrm{EtAlNH})_{n}$, the reaction of the amide $\left(\mathrm{Et}_{2} \mathrm{AlNH}_{2}\right)_{3}$ with a small amount of $\mathrm{AlEt}_{3}$ led to formation of a soluble and fusible glassy solid. They successfully obtained AlN fibers by using melt-spinning of this glassy precursor.

Interrante et al. prepared AlN precursors in a system of alkylaluminum $\left(\mathrm{R}_{3} \mathrm{Al} ; \mathrm{R}=\mathrm{Me}, \mathrm{Et}\right)$-ethylenediamine $\left(\mathrm{H}_{2} \mathrm{NCH}_{2} \mathrm{CH}_{2} \mathrm{NH}_{2}\right.$; en $)$ with various $\mathrm{R}_{3} \mathrm{Al}$ : en ratios $\left(\mathrm{R}_{3} \mathrm{Al}\right.$ : en $=2: 1,1: 1$ and $\left.\left.3: 2) .{ }^{148)}, 156\right)-158\right)$ With respect to these two different ratios $\left(\mathrm{R}_{3} \mathrm{Al}:\right.$ en $=2: 1$ and $\left.1: 1\right)$, they suggested that the two $\mathrm{R}_{3} \mathrm{Al}$-en adducts in the solution were thermolyzed through the formation of $\mathrm{Al}(\mathrm{en}-\mathrm{H})$ derivatives $\left[\mathrm{R}_{3} \mathrm{Al}(\mathrm{en}-\mathrm{H})\left(\mathrm{R}_{2} \mathrm{Al}\right)\right]$, which possessed a five-membered $\mathrm{AlN}_{2} \mathrm{C}_{2}$ ring, as shown in Fig. 6. Thermolysis of the $2: 1$ adduct of $\mathrm{R}_{3} \mathrm{Al}$ and en with a loss of alkane $(\mathrm{RH})$ gave a viscous, soluble polymer $\left[\left(\mathrm{R}_{2} \mathrm{Al}\right)(\mathrm{en}-2 \mathrm{H})\right]_{n}(\mathrm{R}=\mathrm{Et})$. The ceramic yields of insoluble polymeric imides $\left[(\mathrm{RAl})_{2}\right.$ $($ en- $4 \mathrm{H})]_{n}$ obtained by further treatment of the soluble polymers $\left[\left(\mathrm{R}_{2} \mathrm{Al}\right)(\text { en-2H) }]_{n}\right.$ were $55-70$ mass $\%$. (Table. 1$)$ Thermolysis of the $1: 1$ adduct of $\mathrm{R}_{3} \mathrm{Al}$ and en, on the other hand, resulted in the formation of $\mathrm{Al}\left[\left(\mathrm{HNCH}_{2} \mathrm{CH}_{2} \mathrm{NH}\right)\right.$ $\left.\mathrm{AlR}_{2}\right]_{3}(\mathrm{R}=\mathrm{Me})$, possessing a six-coordinated $\mathrm{AlN}_{6}$ and three four-coordinated $\mathrm{AlC}_{2} \mathrm{~N}_{2}$ environments. The ceramic yields of insoluble compounds obtained by further treatment of $\mathrm{Al}\left[\left(\mathrm{HNCH}_{2} \mathrm{CH}_{2} \mathrm{NH}\right) \mathrm{AlR}_{2}\right]_{3}$ were $37-53$ mass \%. With respect to another adduct $\left(\mathrm{R}_{3} \mathrm{Al}:\right.$ en $\left.=3: 2\right)$, they reported heating of the $3: 2$ adduct led to the formation of $\mathrm{RAl}$
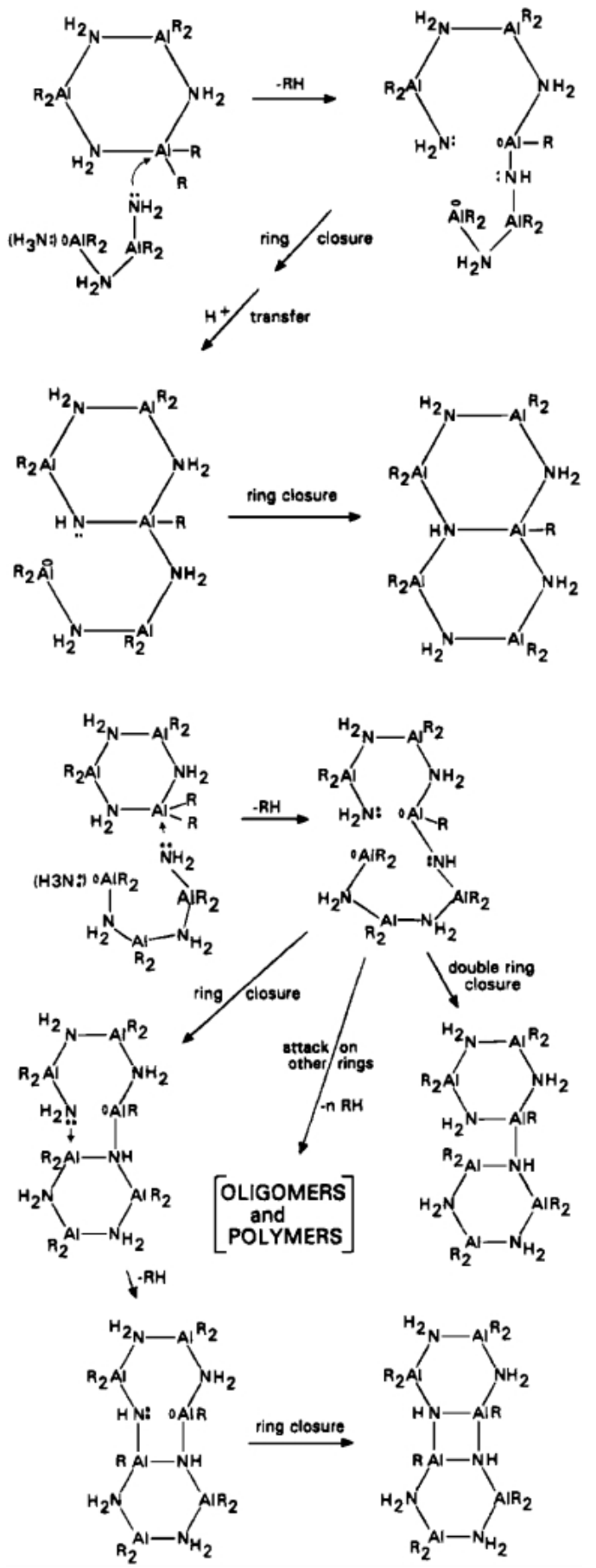

Fig. 5. Proposed mechanism for imide formation. ${ }^{151)}$

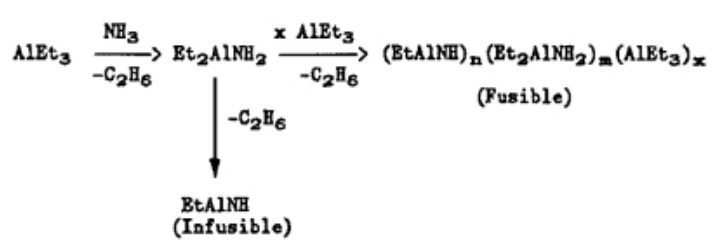

Scheme 1. Preparation of the soluble organoaluminum polymer $\left[(\mathrm{EtAlNH})_{n}\left(\mathrm{Et}_{2} \mathrm{AlNH}_{2}\right)_{m} \mathrm{AlEt}_{3}\right] .{ }^{152)}$

$\left[\left(\mathrm{HNCH}_{2} \mathrm{CH}_{2} \mathrm{NH}\right) \mathrm{AlR}_{2}\right]_{2}$. Further heat treatment of $\mathrm{RAl}$ $\left[\left(\mathrm{HNCH}_{2} \mathrm{CH}_{2} \mathrm{NH}\right) \mathrm{AlR}_{2}\right]_{2}$ gave insoluble solids, which ex- 
hibited relatively higher ceramic yields (59-85 mass\% under an $\mathrm{N}_{2}$ atmosphere) than those of untreated products $\mathrm{RAl}$ $\left[\left(\mathrm{HNCH}_{2} \mathrm{CH}_{2} \mathrm{NH}\right) \mathrm{AlR}_{2}\right]_{2} \quad\left[27-41\right.$ mass $\%$ under an $\mathrm{N}_{2}$ atmosphere $\left.\left(1000^{\circ} \mathrm{C}\right)\right]$.

Jensen reported the preparation of AlN precursors via thermal polymerization of aluminum imine complexs $[\mathrm{RCH}=$ $\left.\left.\mathrm{NAl}\left({ }^{i} \mathrm{Bu}\right)_{2}\right]_{2}{ }^{159)}, 160\right)$ These precursors were thermoplastic and soluble in aprotic solvents, and exhibited low oxygen and moisture sensitivity. Pure AlN was obtained by pyrolysis of $\left[\mathrm{CH}_{3} \mathrm{CH}=\mathrm{NAl}\left({ }^{i} \mathrm{Bu}\right)_{2}\right]_{2}$ with a relatively high ceramic yield. (65 mass \%: pyrolyzed at $1000^{\circ} \mathrm{C}$ under an $\mathrm{N}_{2}$ atmosphere)

3.2 AIN precursors from inorganic compounds containing aluminum, such as $\mathrm{AlH}_{3}$ (and its adduct), $\mathrm{LiAlH}_{4}$ and aluminum halides

An aluminum imido polymer $(\mathrm{HAlNH})_{n}$ containing no carbon, has been actively pursued because the presence of carbon in precursors for nitrides can lead to the formation of undesirable carbon. Wiberg and May first reported the reaction mechanism between $\mathrm{AlH}_{3}$ and ammonia with two different $\mathrm{Al}: \mathrm{N}$ ratios $(\mathrm{Al}: \mathrm{N}=1: 1,1: 3)$ in $1955 .{ }^{161)}$ This approach was reinvestigated by Maya $(\mathrm{Al}: \mathrm{N}=1$ :

Comparison of the 2:1 and 1:1 $\mathrm{R}_{3} \mathrm{Al}$ :en Systems

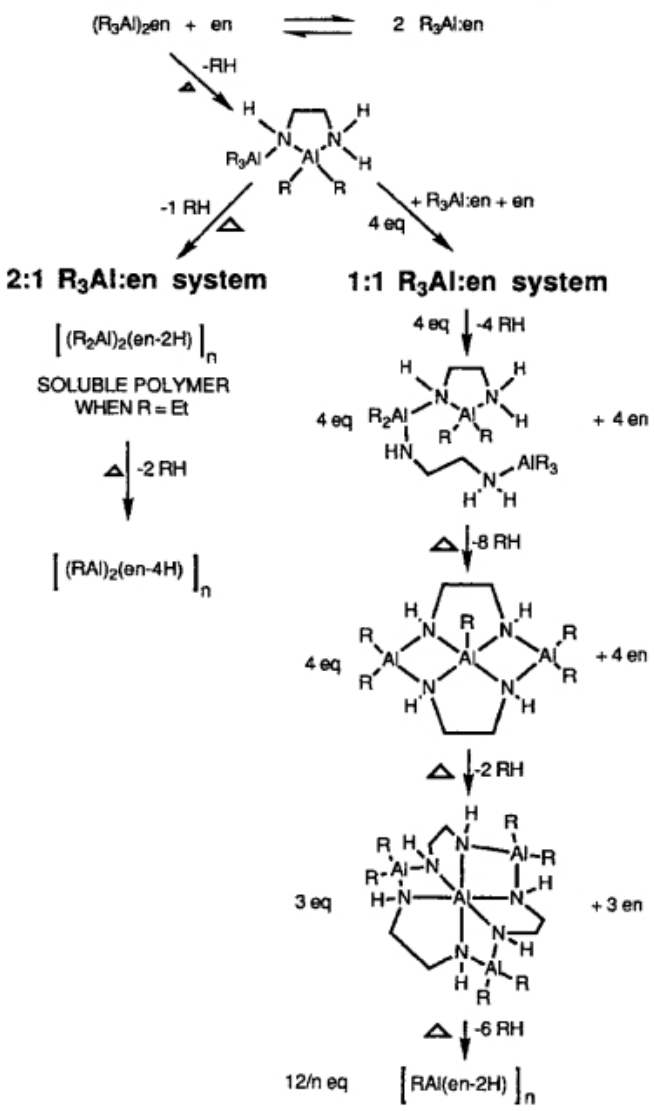

Fig. 6. Suggested pathway for the thermal decomposition of the $\mathrm{R}_{3} \mathrm{Al}$-en adducts. $\left.{ }^{148}\right)$
3) ${ }^{142)}$ and Ochi et al. (Al: N=1:1,1:3), ${ }^{162)}$ as shown in Scheme 2. Maya prepared an insoluble polymeric precursor $\left[\mathrm{Al}\left(\mathrm{NH}_{2}\right)_{0.864}(\mathrm{NH})_{1.069}\right]_{n}$ through a reaction between $\mathrm{AlH}_{3}$. $\mathrm{Et}_{2} \mathrm{O}$ and ammonia with the $1: 3$ reaction (Scheme $2 \mathrm{~A}$ ). AlN was obtained by pyrolysis of $\left[\mathrm{Al}\left(\mathrm{NH}_{2}\right)_{0.864}(\mathrm{NH})_{1.069}\right]_{n}$ at $600^{\circ} \mathrm{C}$. A similar result was reported by Ochi et al. By using the reaction system with an $\mathrm{Al}: \mathrm{N}=1: 1$ ratio, Ochi et al. also prepared a product, which was soluble in THF. (Scheme 2B ${ }^{162)}$ This soluble product was slowly polymerized to form a gel $(\mathrm{HAlNH})_{n}$. The residue of the gel $(\mathrm{HAlNH})_{n}$ pyrolyzed at $1100^{\circ} \mathrm{C}$ in a vacuum contaminated the residual carbon from THF solvent.

Rokensub and Roesky prepared an insoluble amide-imide polymer $\left[\mathrm{Al}\left(\mathrm{NH}_{2}\right) \mathrm{NH}\right]_{n}$ from $\mathrm{AlH}_{3}\left(\mathrm{NMe}_{3}\right)_{2}$ and ammonia. ${ }^{163)}$ Crystalline AIN without impurities (in particular a very low carbon content, lower than $0.3 \%$ ), was obtained by pyrolysis of this insoluble polymer under an $\mathrm{NH}_{3}$ atmosphere. The authors suggested that the reason for the absence of impurities is that two alkylamino groups stabilized the aluminum hydride, protecting it against coordination of oxygencontaining impurities such as ether.

AlN precursors were synthesized, furthermore, by employing lithium aluminum hydride $\left(\mathrm{LiAlH}_{4}\right)$. Janik et al. investigated the reactions of $\mathrm{LiAlH}_{4}$ with $\mathrm{NH}_{4} \mathrm{X}(\mathrm{X}=\mathrm{Cl}, \mathrm{Br})$, $\mathrm{N}_{2} \mathrm{H}_{4}$ and $\mathrm{N}_{2} \mathrm{H}_{4} \cdot \mathrm{HCl}$, leading to the formation of an insoluble polymer: ${ }^{164)}$

$$
\mathrm{LiAlH}_{4}+\mathrm{NH}_{4} \mathrm{X} \longrightarrow 1 / n(\mathrm{HAlNH})_{n}+\mathrm{LiX} \downarrow+3 \mathrm{H}_{2} \uparrow
$$

The insoluble polymer obtained from $\mathrm{LiAlH}_{4}$ and $\mathrm{NH}_{4} \mathrm{Br}$ contained 5-10 mass \% of diethyl ether solvent. The ceramic yield of this polymer was $85-87$ mass $\%$ up to $1000^{\circ} \mathrm{C}$. Pyrolysis in a vacuum or under an $\mathrm{N}_{2}$ atmosphere gave a black powder containing crystalline AlN, suggesting the presence of residual carbon originated from diethyl ether.

Coffman et al. obtained a cyclic trimer $\left(\mathrm{H}_{2} \mathrm{AlNMe}_{2}\right)_{3}$ from $\mathrm{LiAlH}_{4}$ and dimethylamine hydrochloride $\left(\mathrm{Me}_{2} \mathrm{NH} \cdot \mathrm{HCl}\right) .{ }^{165)}$ The cyclic trimer $\left(\mathrm{H}_{2} \mathrm{AlNMe}_{2}\right)_{3}$ was pyrolyzed under a nitrogen atmosphere to yield metallic aluminum, whereas its polymerized product was converted into AlN and Al-O-N

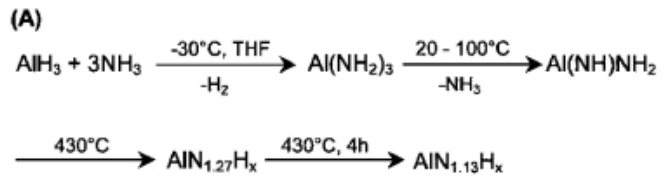

(B)

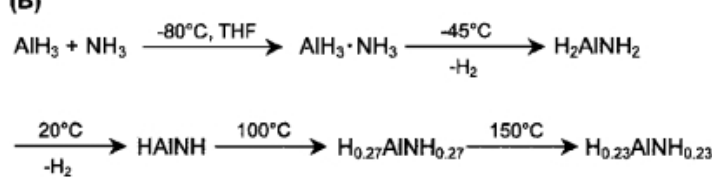

Scheme 2. Reaction schemes for $\mathrm{AlH}_{3}-\mathrm{NH}_{3}$ systems with (A) $\mathrm{AlH}_{3}: \mathrm{NH}_{3}=1: 3$ and (B) $\mathrm{AlH}_{3}: \mathrm{NH}_{3}=1: 1$ ratios. ${ }^{162}$

Table 1. Ceramic Yields of Insoluble AlN Precursors from the $\mathrm{R}_{3} \mathrm{Al}$-en Adducts ${ }^{148)}$

\begin{tabular}{lcccccccc}
\hline \multirow{2}{*}{$\mathrm{R}_{3} \mathrm{Al}$ : en } & \multicolumn{3}{c}{$2: 1$} & \multicolumn{3}{c}{$1: 1$} & & \multicolumn{2}{c}{$3: 2$} \\
\cline { 3 - 8 } & & $\mathrm{R}=\mathrm{Me}$ & $\mathrm{R}=\mathrm{Et}$ & $\mathrm{R}=\mathrm{Me}$ & $\mathrm{R}=\mathrm{Et}$ & $\mathrm{R}=\mathrm{Me}$ & $\mathrm{R}=\mathrm{Et}$ \\
\hline \multirow{2}{*}{ Ceramic yields / mass\% } & $\mathrm{N}_{2}$ & 70 & 64 & 37 & 45 & 85 & 59 \\
& $\mathrm{NH}_{3}$ & 56 & 55 & 53 & 49 & 75 & 31 \\
\hline
\end{tabular}


ceramics. ( 75.5 mass $\%$; pyrolyzed at $1200^{\circ} \mathrm{C}$ under an $\mathrm{N}_{2}$ atmosphere)

AlN precursors were also prepared from aluminum halide as an aluminum source. The aluminum amino-imino polymer $\left[\mathrm{Al}\left(\mathrm{NH}_{2}\right) \mathrm{NH}\right]_{n}$ was prepared from $\mathrm{AlBr}_{3}$ and $\mathrm{KNH}_{2} \cdot{ }^{142)} \mathrm{AlN}$ was obtained by pyrolysis of $\left[\mathrm{Al}\left(\mathrm{NH}_{2}\right) \mathrm{NH}\right]_{n}$ at $800^{\circ} \mathrm{C}$ in a vacuum.

$$
\begin{aligned}
& \mathrm{AlBr}_{3}+\mathrm{KNH}_{2} \\
& \longrightarrow 1 / n\left[\mathrm{Al}\left(\mathrm{NH}_{2}\right) \mathrm{NH}\right]_{n}+3 \mathrm{KBr} \downarrow+\mathrm{NH}_{3} \uparrow
\end{aligned}
$$

A reaction between $\mathrm{AlCl}_{3}$ and hexamethyldisilazane $\left[\left(\mathrm{Me}_{3} \mathrm{Si}\right)_{2} \mathrm{NH}\right]$ occurred at $60-100^{\circ} \mathrm{C}$ to form the compounds $\left(\mathrm{Cl}_{2} \mathrm{AlNHSiMe}_{3}\right)_{2}$ with the simultaneous loss of one mol of $\mathrm{Me}_{3} \mathrm{SiCl}{ }^{166), 167)}$ Thermolysis of $\left(\mathrm{Cl}_{2} \mathrm{AlNHSiMe}_{3}\right)_{2}$ at 170 $200^{\circ} \mathrm{C}$ led to the formation of a polymer $(\mathrm{ClAlNH})_{n}$ and further pyrolysis of $(\mathrm{ClAlNH})_{n}$ in a vacuum or under an $\mathrm{NH}_{3}$ atmosphere gave crystalline AlN. ${ }^{168)}$ Riedel et al. revealed that the residue pyrolyzed above $1000^{\circ} \mathrm{C}$ contained a small amount of silicon and carbon and suggested that all the carbon atoms seemed to be bonded to silicon as SiC. ${ }^{169)}$ Hyodo et al. prepared an $\mathrm{AlN}$ precursor through a reaction between $\mathrm{AlCl}_{3}$ and ethylenediamine. Pyrolysis at $1200^{\circ} \mathrm{C}$ for $5 \mathrm{~h}$ led to formation of crystalline AlN. ${ }^{170)}$

Poly(alkyliminoalane)s are well-known cage-type compounds possessing an Al-N backbone and have usually been prepared via the following three reaction: ${ }^{171}$ )

$$
\begin{aligned}
& \left.\mathrm{AlH}_{3} \text { (or its adduct, e.g. } \mathrm{H}_{3} \mathrm{Al} \cdot \mathrm{NMe}_{3}\right)+\mathrm{RNH}_{2} \\
& \stackrel{\longrightarrow}{\longrightarrow} 1 / n(\mathrm{HAlNR})_{n}+2 \mathrm{H}_{2} \uparrow \\
& \mathrm{LiAlH}_{4}+\mathrm{RNH}_{2} \longrightarrow 1 / n(\mathrm{HAlNR})_{n}+\mathrm{LiH} \downarrow+2 \mathrm{H}_{2} \uparrow \\
& \mathrm{LiAlH}_{4}+\mathrm{RNH}_{2} \cdot \mathrm{HCl} \\
& \stackrel{\longrightarrow}{\longrightarrow} 1 / n\left(\mathrm{HAlNR}_{n}+\mathrm{LiCl} \downarrow+3 \mathrm{H}_{2} \uparrow\right.
\end{aligned}
$$

Table 2 summarizes the aggregation degree of poly (alkyliminoalane)s, and their structures are demonstrated in Fig. 7. ${ }^{172), 173)}$ A novel cage-type compound, $\mathrm{H}_{6} \mathrm{Al}_{6}\left(\mathrm{~N}^{i} \mathrm{Pr}\right)_{4}$ $\left[\mathrm{NSi}\left(\mathrm{NMe}_{2}\right)_{3}\right]_{2}$, has recently been prepared by a reaction of $\mathrm{H}_{2} \mathrm{NSi}\left(\mathrm{NMe}_{2}\right)_{3}$ with $\left.\left(\mathrm{HAlN}{ }^{i} \mathrm{Pr}\right)_{6} \cdot{ }^{174}\right)$

Pyrolytic organic-to-inorganic conversions of $\left(\text { HAlN }^{i} \mathrm{Pr}\right)_{n}{ }^{175)-178)}(n$ is mainly 6$)$ and (HAlNEt $\left.\left.)_{n}{ }^{177)}, 179\right), 180\right)$ ( $n$ is mainly 8 ) to AlN have been investigated. Table 3 summarizes the ceramic yields and chemical compositions of the pyrolyzed residue. The residues pyrolyzed under an $\mathrm{Ar}$ atmosphere consisted of crystalline AlN and amorphous carbon. The residues pyrolyzed under an $\mathrm{NH}_{3} / \mathrm{N}_{2}$ atmosphere, on the contrary, were white solids possessing an extremely small amount of carbon (0.1-0.5 mass\%). A possible reaction during pyrolysis under an $\mathrm{NH}_{3} / \mathrm{N}_{2}$ atmosphere was an amine-exchange reaction as follows:

$$
=\mathrm{NR}+\mathrm{NH}_{3} \longrightarrow=\mathrm{NH}+\mathrm{RNH}_{2}
$$

The loss of aluminum in the pyrolysis of these oligomers under an $\mathrm{NH}_{3} / \mathrm{N}_{2}$ atmosphere was suppressed, as compared with that under an Ar atmosphere. The lower loss could be ascribed to a cross-linking reaction involving the $\mathrm{NH}$ bonds formed by the amine-exchange reaction.

The pyrolytic conversion of these oligomers can be divided into two stages. ${ }^{178), 180)}$ In the first stage, the heterolytic cleavage of Al-N bonds led to formation of nitrogen terminals $(=\mathrm{N}:)$, which attacked aluminum atoms in another cage (with further attacks following), resulting in cage-opening polymerization. (Fig. 8) In the second stage, the alkenes were generated via two possible mechanisms: (A) homolytic cleavage of $\mathrm{C}-\mathrm{N}$ bonds and subsequent $\beta$-elimination of hydrogen radicals; and (B) concerted $\beta$-elimination. (Scheme 3) The alkanes were also generated by hydrogen abstraction of radicals (as shown in Scheme 4C).

The poly (alkyliminoalane) structures can be modified by using two different kinds of amines. To achieve further increases in ceramic yields, AlN precursors possessing $\mathrm{C}=\mathrm{C}$ bonds were prepared from $\mathrm{LiAlH}_{4}$, allylamine hydrochloride $\left(\right.$ allylNH$\left.H_{2} \cdot \mathrm{HCl}\right)$ and $\mathrm{EtNH}_{2} \cdot \mathrm{HCl}^{181}$ ) The ceramic yields of

Table 2. Aggregation Degree of (HAlNR $)_{n}$ and their Structures $^{171)-173)}$

\begin{tabular}{ccc}
\hline $\mathrm{R}$ & aggergation degree $^{a}$ & structure $^{b}$ \\
\hline $\mathrm{Me}$ & - & highly cross-linked \\
$\mathrm{Et}$ & $6,7,8$ & cage-type \\
${ }^{n} \mathrm{Pr}$ & 4,6 & cage-type \\
${ }^{i} \mathrm{Pr}$ & $6,7,8$ & cage-type \\
${ }^{n} \mathrm{Bu}$ & 6 & cage-type \\
${ }^{i} \mathrm{Bu}$ & 6 & cage-type \\
${ }^{s} \mathrm{Bu}$ & 4 & cage-type \\
${ }^{t} \mathrm{Bu}$ & 4,6 & cage-type \\
$\mathrm{C}_{6} \mathrm{H}_{11}$ & cage-type \\
\hline
\end{tabular}

${ }^{a}$ main components. ${ }^{b}$ see Fig. 7

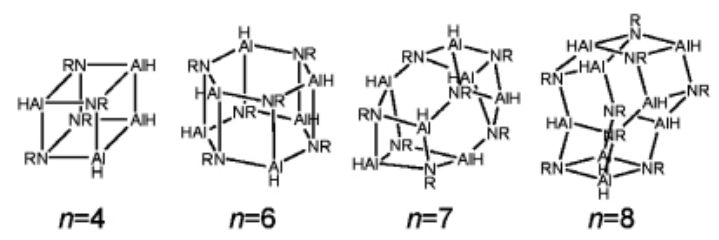

Fig. 7. Structure of poly (alkyliminoalane) $\left[(\mathrm{HAlNR})_{n}, n=4,6,7\right.$, $8] .{ }^{172)}$

Table 3. Ceramic Yields, Loss of Aluminum and Chemical Compositions of the Residues Pyrolyzed of $\left(\right.$ HAlN ${ }^{i} \mathrm{Pr}{ }_{n}$ and $(\mathrm{HAlNEt})_{n}{ }^{175)-177), 179)}$

\begin{tabular}{ccccc}
\hline & \multicolumn{2}{c}{$\left(\mathrm{HAIN}^{\prime} \mathrm{Pr}\right)_{n}$} & \multicolumn{2}{c}{$(\mathrm{HAINEt})_{m}$} \\
\cline { 2 - 5 } & $\mathrm{Ar}$ & $\mathrm{NH}_{3}-\mathrm{N}_{2}$ & $\mathrm{Ar}$ & $\mathrm{NH}_{3}-\mathrm{N}_{2}$ \\
\hline ceramic yield / mass\% & 32 & 47 & 50 & 57 \\
loss of aluminium / mass\% & & & 36 & 7 \\
elemental analysis & 55 & 14 & & \\
$\mathrm{Al} /$ mass\% & & & $48.5(1)$ & $61.9(1)$ \\
$\mathrm{N} /$ mass\% & $45.2(1)$ & $58.1(1)$ & $23.5(0.93)$ & $28.7(0.89)$ \\
O/mass\% & $20.8(0.89)$ & $28.9(0.96)$ & $3.7(0.13)$ & $5.6(0.15)$ \\
$\mathrm{C} /$ mass\% & $5.5(0.20)$ & $7.5(0.22)$ & $17.1(0.79)$ & $0.1(0.004)$ \\
total / mass\% & $20.6(1.03)$ & $0.5(0.02)$ & 92.8 & 96.3 \\
\hline
\end{tabular}

${ }^{a}$ The loss of aluminum [Loss (Al)] during pyrolysis can be calculated by the following equation, based on the aluminum in the ceramic residue $\left(C_{\mathrm{A})}\right)$, the aluminum in precursors $\left(P_{\mathrm{Al}}\right)$ and the ceramic yield $(Y)$. Loss $(\mathrm{Al})[\%]=\left[\left(P_{\mathrm{Ar}} Y \times C_{\mathrm{Al}}\right) / P_{\mathrm{Al}}\right] \times 100$ 


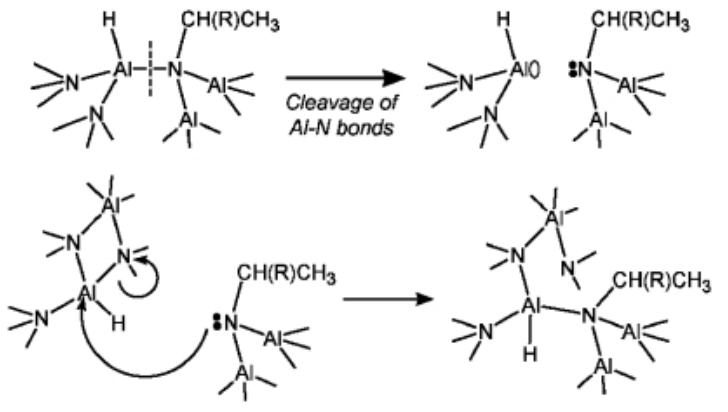

Fig. 8. Proposed mechanism for the thermal polymerization of $\left[\mathrm{HAlNCH}(\mathrm{R}) \mathrm{CH}_{3}\right]_{n} .\left(\mathrm{R}=\mathrm{H}, \mathrm{CH}_{3}\right)^{178)}$

(A)

$$
\begin{aligned}
& =\mathrm{NCH}(\mathrm{R}) \mathrm{CH}_{3} \longrightarrow=\mathrm{N}^{\cdot}+{ }^{\circ} \mathrm{CH}(\mathrm{R}) \mathrm{CH}_{3} \\
& { }^{\mathrm{C}} \mathrm{CH}(\mathrm{R}) \mathrm{CH}_{3} \longrightarrow \mathrm{RCH}=\mathrm{CH}_{2}+\mathrm{H}^{\cdot}
\end{aligned}
$$

(B)

$$
=\mathrm{NCH}(\mathrm{R}) \mathrm{CH}_{3} \longrightarrow=\mathrm{NH}+\mathrm{RCH}=\mathrm{CH}_{2}
$$

\section{(C)}

$$
\cdot \mathrm{CH}(\mathrm{R}) \mathrm{CH}_{3} \stackrel{\mathrm{H} \text { abstraction }}{\longrightarrow} \mathrm{CH}_{2}(\mathrm{R}) \mathrm{CH}_{3}
$$

Scheme 3. Proposed mechanism for the formation of alkanes and alkenes during pyrolysis of $\left[\mathrm{HAlNCH}(\mathrm{R}) \mathrm{CH}_{3}\right]_{n}$. $\left(\mathrm{R}=\mathrm{H}, \mathrm{CH}_{3}\right)^{178)}$

these precursors were higher than those of (HAlNEt) $n$ and $\left(\mathrm{HAlN}^{i} \mathrm{Pr}\right)_{n}$, a result which could be ascribed to cross-linking involving a hydroalumination reaction and possibly polymerization of allyl groups during pyrolysis. To improve the solubility of insoluble poly (methyliminoalane) (HAlNMe) ${ }_{n}$, poly (methyl iminoalane-co-dimethyl aminoalane)s were prepared. ${ }^{182)}$ The partial substitution of dimethylamino groups for methylimino groups in $(\mathrm{HAlNMe})_{n}$ resulted in the formation of a soluble polymeric/oligometric precursor. The ceramic yields of these precursors were close to those of $(\mathrm{HAlNEt})_{n}$ and $\left(\mathrm{HAlN}^{i} \mathrm{Pr}\right)_{n}$, and these precursors had possible advantages for achieving desirable rheological properties because of their polymeric structures.

3.3 AIN films and imido compounds possessing an Al-N backbone prepared via the CVD process

For the preparation of AlN films via the CVD process using AlN precursors, Interrante et al. prepared smooth, transparent AlN films, which were deposited on silicon and silica substrates at $400-800^{\circ} \mathrm{C}$ in a low temperature chemical vapor deposition system using a cyclic trimer $\left(\mathrm{Me}_{2} \mathrm{AlNH}_{2}\right)_{3} \cdot{ }^{183)}$ They also investigated the reaction mechanism during the CVD process and the influence of temperature on the trimer-dimer equilibrium by identification of the gas-phase product using a molecular beam-mass spectrometer. ${ }^{184), 185)}$ Timoshkin et al. revealed that the formation of imide compounds (clusters) during the CVD processes was feasible both thermodynamically and kinetically. ${ }^{172)}$ The authors suggested that the CVD processes are capable of offering a route to the fabrication of nanoparticles with the desired stoichiometries using these

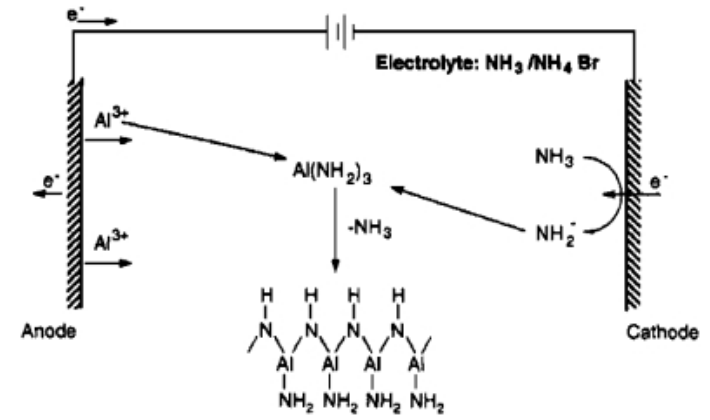

Fig. 9. Proposed in-cell chemistry leading to formation of an AIN precursor. ${ }^{192)}$

clusters as single-source precursors.

\subsection{Electrochemical preparation of AIN}

AlN precursors also have been prepared by electrolysis of metallic aluminum in solutions, which consist of an alkylamine, a solvent and a supporting electrolyte or liquid ammonia. The electrochemical preparation of AlN was first reported by Maya in 1986. ${ }^{142)}$ An aminoalane $\mathrm{Al}\left(\mathrm{NH}_{2}\right)_{3}$ was prepared by anodic oxidation of metallic aluminum in liquid ammonia containing $\mathrm{KNH}_{2}$ and $\mathrm{NH}_{4} \mathrm{Br}$. Rüssel et al. ${ }^{186)-190)}$ reported that anodic oxidation in an electrolyte consisting of a primary amine, acetonitrile and tetrabutylammonium bromide gave an intermediate compound $\left[\mathrm{Al}(\mathrm{NHR})_{3}\right]$. Further heating of $\mathrm{Al}(\mathrm{NHR})_{3}$ in a vacuum at $150^{\circ} \mathrm{C}$ led to the formation of a polymeric gel. A crystalline AlN powder was obtained by pyrolysis of this polymeric gel at $1200^{\circ} \mathrm{C}$ (42 mass\%). AlN coating ${ }^{188)}$ and oxynitride glass ${ }^{190)}$ were also prepared from the polymeric gel. Crooks et al., on the other hand, prepared a insoluble polymer $\left[\mathrm{Al}\left(\mathrm{NH}_{2}\right)(\mathrm{NH})\right]_{n}$ and a by-product $\left[\mathrm{Al}\left(\mathrm{NH}_{3}\right){ }_{6} \mathrm{Br}_{3}\right]$ in an electrolyte consisting of ammonium bromide and ammonia (Fig. 9). ${ }^{191)-193)}$ During pyrolysis of this mixture in $\mathrm{NH}_{3}$ up to $600^{\circ} \mathrm{C}, \mathrm{NH}_{3}$ condensation of the polymer occurred, followed by elimination of $\mathrm{NH}_{3}$ from both the polymer and $\mathrm{Al}\left(\mathrm{NH}_{3}\right)_{6} \mathrm{Br}_{3}$ and/or sublimation of $\mathrm{Al}\left(\mathrm{NH}_{3}\right)_{6} \mathrm{Br}_{3}$. After pyrolysis at $1100^{\circ} \mathrm{C}$ in $\mathrm{NH}_{3}$, only an AlN powder was obtained. In addition to the preparation of the AlN powder, this polymer was used for AlN coating onto an Si substrate by an electrophoresis technique. Shimada et al. prepared AlN powders and films by the combined method of electrolysis of metallic $\mathrm{Al}$ in isopropylamine and further pyrolysis. ${ }^{194)}$

\section{Conclusions}

This review presents an overview of the preparation of precursors possessing an $\mathrm{Al}-\mathrm{N}$ backbone and their conversion into AlN. Since Al-N bonds are easily formed via a Lewis acid-base reaction, most polymeric compounds possessing the Al-N backbone have highly cross-linked structures and are thus basically insoluble in common organic solvents. Formation of such cross-linked structures can be suppressed by using a primary amine with a bulky substituent, but AlN precursors possessing bulky substituents can lead to high carbon content in resulting materials, which is a large drawback in the preparation of nitrides due to the resulting degradation of their potential. Cyclic and cage-type AlN precursors are usually soluble, on the other hand, but exhibit low ceramic yields. The ceramic yields of these soluble precursors are expected to increase with post-treatment, which can give rise to degradation of their solubility. In order to capitalize on the advantages of the pyrolytic organic-to-inorganic conversion process, the 
development of AlN precursors with high solubility, high ceramic yields and low carbon content will be consequently required.

Acknowledgements The authors gratefully thank Prof. Kazuyuki Kuroda, Department of Applied Chemistry at Waseda University, for valuable discussion and $21 \mathrm{COE}$ "Practical NanoChemistry" from MEXT, Japan for financial support.

\section{References}

1) Wynne, K. J. and Rice, R. W., Ann. Rev. Mater. Sci., Vol. 14, pp. 297-334 (1984).

2) Pouskouleli, G., Ceram. Int., Vol. 15, pp. 213-229 (1989).

3) Narula, C. K., "Ceramic Precursor Technology and Its Applications," Marcel Dekker, NY (1995).

4) Bill, J. and Aldinger, F., Adv. Mater., Vol. 7, pp. 775-787 (1995).

5) Seyferth, D., "Silicon-Based Polymer Science, A Comprehensive Resourse"; in Advanced in Chemistry Series, Vol. 224, Ed. by Zeigler, J. M. and Gordon Fearon, F. W., American Chemical Society, Washington D. C. (1990) pp. 565-591.

6) Slack, G. A., J. Phys. Chem. Solids, Vol. 34, pp. 321-325 (1973).

7) Selvaduray, G. and Sheet, L., Mater. Sci. Technol., Vol. 9, pp. 463-473 (1993).

8) Liao, B. X., Li, Y. K. and Lu, Y., J. Mater. Chem., Vol. 3, pp. 117-127 (1993).

9) Slack, G. A., Tanzilli, R. A., Pohl, R. O. and Vandersande, J. W., J. Phys. Chem. Solids, Vol. 48, pp. 641-647 (1987).

10) Yim, W. M., Stofko, E. J., Zanzucchi, P. J., Pankove, J. I., Ettenberg, M. and Gilbert, S. L., J. Appl. Phys., Vol. 44, pp. 292-296 (1973).

11) Werdecker, W. and Aldinger, F., IEEE, Trans. Compon., Hybrids, Manuf. Technol., Vol. CHMT-7, pp. 399-404 (1984).

12) Sheppart, L. M., Am. Ceram. Soc. Bull., Vol. 69, pp. 1801-1812 (1990).

13) Kuramoto, N. and Taniguchi, H., J. Mater. Sci. Lett., Vol. 3, pp. 471-474 (1984).

14) Kurokawa, Y., Utsumi, K., Takamizawa, H., Kamata, T. and Noguchi, S., IEEE, Trans. Compon., Hybrids, Manuf. Technol., Vol. CHMT-8, pp. 247-252 (1985).

15) Callahan, D. L. and Thomas, G., J. Am. Ceram. Soc., Vol. 73, pp. 2167-2170 (1990).

16) Interrante, L. V., Carpenter, II, L. E., Whitmarsh, C., Lee, W., Garbauskas, M. and Slack, G. A., Mater. Res. Soc. Symp. Proc., Vol. 73, pp. 359-366 (1986).

17) Neumayer, D. A. and Ekerdt, J. G., Chem. Mater., Vol. 8, pp. 9-25 (1996).

18) Schenk, H. P. D., Kaiser, U., Kipshidze, G. D., Fissel, A., Kräußlich, J., Hobert, H., Schulze, J. and Richter, W., Mater. Sci. Eng., B, Vol. B59, pp. 84-87 (1999).

19) Sheppard, L. M., Am. Ceram. Soc. Bull., Vol. 69, pp. 1801-1812 (1990).

20) Mroz, Jr., T. J., Am. Ceram. Soc. Bull., Vol. 71, pp. 782-784 (1992).

21) Lefort, P. and Billy, M., J. Am. Ceram. Soc., Vol. 76, pp. 2295-2299 (1993).

22) Bachelard, R. and Joubert, P., Mater. Sci. Eng., A, Vol. A109, pp. 247-251 (1989).

23) Chen, H. K., Lin, C. I. and Lee, C., J. Am. Ceram. Soc., Vol. 77, pp. 1753-1756 (1994).

24) Ide, T., Komeya, K., Meguro, T. and Tatami, J., J. Am. Ceram. Soc., Vol. 82, pp. 2993-2998 (1999).

25) Komeya, K., Kitagawa, I. and Meguro, T., J. Ceram. Soc. Japan, Vol. 102, pp. 670-674 (1994) [in Japanese].

26) Lee, B. I. and Einarsrud, M. A., J. Mater, Sci. Lett., Vol. 9, pp. 1389-1391 (1990).

27) Hashimoto, N., Sawada, Y., Bando, T., Yoden, H. and Deki, S., J. Am. Ceram. Soc., Vol. 74, pp. 1282-1286 (1991).
28) Sugahara, Y., Kuroda, K. and Kato, C., J. Mater. Sci., Vol. 23, pp. 3572-3577 (1988).

29) Sugahara, Y., Yokoyama, N., Kuroda, K. and Kato, C., Ceram. Int., Vol. 14, pp. 163-167 (1988).

30) Sugahara, Y., Kuroda, K. and Kato, C., J. Am. Ceram. Soc., Vol. 67, pp. C-247-C-248 (1984).

31) Hotta, N., Fukui, K., Furukawa, Y., Kameshima, S., Kimura, I. and Kanatani, M., J. Ceram. Soc. Japan, Vol. 102, pp. 1032-1036 (1994) [in Japanese].

32) Weimer, A. W., Cochran, G. A., Eisman, G. A., Henley, J. P., Hook, B. D., Mills, L. K., Guiton, T. A., Knudsen, A. K., Nicholas, N. R., Volmering, J. E. and Moore, W. G., J. Am. Ceram. Soc., Vol. 77, pp. 3-18 (1994).

33) Komeya, K., Matsukaze, N. and Meguro, T., J. Ceram. Soc. Japan, Vol. 101, pp. 1319-1323 (1993).

34) Nickel, K. G., Riedel, R. and Petzow, G., J. Am. Ceram. Soc., Vol. 72, pp. 1804-1810 (1989).

35) Riedel, R. and Gaudl, K. U., J. Am. Ceram. Soc., Vol. 74, pp. 1331-1334 (1991).

36) Goto, T., Tsuneyoshi, J., Kaya, K. and Hirai, T., J. Mater. Sci., Vol. 27, pp. 247-254 (1992).

37) Jones, A. L., Whitehouse, C. R. and Roberts, J. S., Chem. Vap. Deposition, Vol. 1, pp. 65-74 (1995).

38) Kimura, I., Hotta, N., Nukui, H., Saito, N. and Yasukawa, S., J. Mater, Sci. Lett., Vol. 7, pp. 66-68 (1988).

39) Yive, N. S. C. K., Corriu, R. J. P., Leclercq, D., Mutin, P. H. and Vioux, A., New J. Chem., Vol. 15, pp. 85-92 (1991).

40) Beck, J. S., Albani, C. R., McGhie, A. R., Rothman, J. B. and Sneddon, L. G., Chem. Mater., Vol. 1, pp. 433-438 (1989).

41) Winter, G., German Patent 2236078 (1974).

42) Verbeek, W., US Patent 3853567 (1974).

43) Yajima, S., Hayashi, J. and Omori, M., Chem. Lett., pp. 931-934 (1975).

44) Yajima, S., Okamura, K. and Hayashi, J., Chem. Lett., pp. 1209-1212 (1975).

45) Yajima, S., Hayashi, J., Omori, M. and Okamura, K., Nature, Vol. 261, pp. 683-685 (1976).

46) Yajima, S., Hasegawa, Y., Hayashi, J. and Iimura, M., J. Mater. Sci., Vol. 13, pp. 2569-2576 (1978).

47) Yajima, S., Okamura, K., Hayashi, J. and Omori, M., J. Am. Ceram. Soc., Vol. 59, pp. 324-327 (1976).

48) Yajima, S., Omori, M., Hayashi, J., Okamura, K., Matsuzawa, T. and Liaw, C.-F., Chem. Lett., pp. 551-554 (1976)

49) Shiina, K. and Kumada, M., J. Org. Chem., Vol. 23, pp. 139-139 (1958).

50) Sakurai, H., Koh, R., Hosomi, A. and Kumada, M., Bull. Chem. Soc. Jpn., Vol. 39, pp. 2050-2051 (1966).

51) Sakurai, H., Hosomi, A. and Kumada, M., Chem. Commun., pp. 930-930 (1968).

52) Yajima, S., Hayashi, J. and Okamura, K., Nature, Vol. 266, pp. 521-522 (1977).

53) Duboudin, F., Birot, M., Babot, O., Dunoguès, J. and Calas, R., J. Organomet. Chem., Vol. 341, pp. 125-132 (1988).

54) Ishikawa, T., Comp. Sci. Tech., Vol. 51, pp. 135-144 (1994).

55) Yamamura, T., Ishikawa, T., Shibuya, M., Hisayuki, T. and Okamura, K., J. Mater. Sci., Vol. 23, pp. 2589-2594 (1988).

56) Okamura, K., Composites, Vol. 18, pp. 107-120 (1987).

57) Birot, M., Pillot, J.-P. and Dunoguès, J., Chem. Rev., Vol. 95, pp. 1443-1477 (1995).

58) Laine, R. M. and Babonneau, F., Chem. Mater., Vol. 5, pp. 260-279 (1993).

59) Richter, R., Roewer, G., Böhme, U., Busch, K., Babonneau, F., Martin, H. P. and Müller, E., Appl. Organomet. Chem., Vol. 11, pp. 71-106 (1997).

60) Wu, H.-J. and Interrante, L. V., Chem. Mater., Vol. 1, pp. 564-568 (1989).

61) Wu, H.-J. and Interrante, L. V., Macromolecules, Vol. 25, pp. 1840-1841 (1992).

62) Bacqué, E., Pillot, J. P., Birot, M. and Dunoguès, J., Macromolecules, Vol. 21, pp. 30-34 (1988). 
63) Bacqué, E., Pillot, J. P., Birot, M. and Dunoguès, J., Macromolecules, Vol. 21, pp. 34-38 (1988).

64) Bacqué, E., Pillot, J. P., Birot, M., Dunoguès, J., Lapouyade, P., Bouillon, E. and Pailler, R., Chem. Mater., Vol. 3, pp. 348-355 (1991).

65) Boury, B., Carpenter, L. and Corriu, R. J. P., Angew. Chem. Int. Ed. Engl., Vol. 29, pp. 785-787 (1990).

66) Boury, B., Corriu, R. J. P., Leclercq, D., Mutin, P. H., Planeix, J. M. and Vioux, A., Organometallics, Vol. 10, pp. 1457-1461 (1991).

67) Boury, B., Corriu, R. J. P. and Douglas, W. E., Chem. Mater., Vol. 3, pp. 487-489 (1991).

68) Schilling, Jr., C. L., Brit. Polym. J., Vol. 18, pp. 355-358 (1986).

69) Schilling, Jr., C. L., Wesson, J. P. and Williams, T. C., Am. Ceram. Soc. Bull., Vol. 62, pp. 912-915 (1983).

70) West, R., J. Organomet. Chem., Vol. 300, pp. 327-346 (1986).

71) West, R., David, L. D., Djurovich, P. I., Yu, H. and Sinclair, R., Am. Ceram. Soc. Bull., Vol. 62, pp. 899-903 (1983).

72) West, R., "Ultrastructure Processing of Ceramics, Glasses and Composites," Ed. by Hench, L. L. and Ulrich, D. R., Wiley, NY (1984) pp. 235-244.

73) Seyferth, D. and Yu, Y.-F., U.S. Patent 4639501 (1987).

74) Seyferth, D., Sobon, C. A. and Borm, J., New J. Chem., Vol 14, pp. 545-547 (1989).

75) Zhang, Z. F., Babonneau, F., Laine, R. M., Mu, Y., Harrod, J. F. and Rahn, J. A., J. Am. Ceram. Soc., Vol. 74, pp. 670-673 (1991).

76) Seyferth, D., Wood, T. G., Tracy, H. J. and Robison, J. L., J. Am. Ceram. Soc., Vol. 75, pp. 1300-1302 (1992).

77) Boury, B., Bryson, N. and Soula, G., Chem. Mater., Vol. 10, pp. 297-303 (1998).

78) Kho, J. G., Min, D. S. and Kim, D. P., J. Mater. Sci. Lett., Vol. 19, pp. 303-305 (2000).

79) Hong, L. Y., Cao, F., Kim, D. J., Woo, H. G., Kim, B. H., Cho, M. S., Li, X. D. and Kim, D. P., J. Organomet. Chem., Vol. 687, pp. 27-32 (2003).

80) Kroke, E., Li, Y. L., Konetschny, C., Lecomte, E., Fasel, C. and Riedel, R., Mater. Sci. Eng. R, Vol. R26, pp. 97-199 (2000).

81) Seyferth, D., Wiseman, G. H. and Prud'homme, C., J. Am. Ceram. Soc., Vol. 66, pp. C-13-C-14 (1983).

82) Seyferth, D. and Wiseman, G. H., "In Ultrastructure Processing of Ceramics, and Composites," Ed. by Hench, L. L. and Ulrich, D. R., John Wiley \& Sons, NY (1984) pp. 265-271.

83) Seyferth, D. and Wiseman, G. H., J. Am. Ceram. Soc., Vol. 67, pp. C-132-C-133 (1984).

84) Blum, Y. and Laine, R. M., Organometallics, Vol. 5, pp. 2081-2086 (1986).

85) Blum, Y., Schwartz, K. B. and Laine, R. M., J. Mater. Sci., Vol. 24, pp. 1707-1718 (1989).

86) Yive, N. S. C. K., Corriu, R. J. P., Leclercq, D., Mutin, P. H. and Vioux, A., Chem. Mater., Vol. 4, pp. 141-146 (1992).

87) Yive, N. S. C. K., Corriu, R. J. P., Leclercq, D., Mutin, P. H. and Vioux, A., Chem. Mater., Vol. 4, pp. 1263-1271 (1992).

88) Bahloul, D., Pereira, M., Goursat, P., Yive, N. S. C. K. and Corriu, R. J. P., J. Am. Ceram. Soc., Vol. 76, pp. 1156-1162 (1993).

89) Kawamura, N. and Isoda, T., JETI, Vol. 38, pp. 104-108 (1990).

90) Yokoyama, Y., Nanba, T., Yasui, I., Kaya, H., Maeshima, T. and Isoda, T., J. Am. Ceram. Soc., Vol. 74, pp. 654-657 (1991)

91) Fazen, P. J., Beck, J. S., Lynch, A. T., Remsen, E. E. and Sneddon, L. G., Chem. Mater., Vol. 2, pp. 96-97 (1990).

92) Fazen, P. J. and Sneddon, L. G., Organometallics, Vol. 13, pp. 2867-2868 (1994)

93) Fazen, P. J., Remsen, E. E., Beck, J. S., Carroll, P. J., McGhie, A. R. and Sneddon, L. G., Chem. Mater., Vol. 7, pp. 1942-1956 (1995).
94) Chan, V. Z. H., Rothman, J. B., Palladino, P., Sneddon, L. G. and Composto, R. J., J. Mater. Res., Vol. 11, pp. 373-380 (1996).

95) Wideman, T. and Sneddon, L. G., Chem. Mater., Vol. 8, pp. 3-5 (1996).

96) Wideman, T., Remsen. E. E., Cortez, E., Chlanda, V. L. and Sneddon, L. G., Chem. Mater., Vol. 10, pp. 412-421 (1998).

97) Wideman, T., Fazen, P. J., Su, K., Remesen, E. E., Zank, G. A. and Sneddon, L. G., Appl. Organomet. Chem., Vol. 12, pp. 681-693 (1998).

98) Narula, C. K., Schaeffer, R., Paine, R. T., Datye, A. and Hammetter, W. F., J. Am. Chem. Soc., Vol. 109, pp. 5556-5557 (1987).

99) Paine, R. T. and Narula, C. K., Chem. Rev., Vol. 90, pp. 73-91 (1990).

100) Lynch, A. T. and Sneddon, L. G., J. Am. Chem. Soc., Vol. 109, pp. 5867-5868 (1987).

101) Lynch, A. T. and Sneddon, L. G., J. Am. Chem. Soc., Vol. 111, pp. 6201-6209 (1989).

102) Su, K., Remsen, E. E., Thompson, H. M. and Sneddon, L. G., Macromolecules, Vol. 24, pp. 3760-3766 (1991).

103) Chawla, K., "Ceramic Matrix Composites," Chapman and Hall, London, UK (1993).

104) Walker, B. E., Rice, R. W., Becher, P. F., Bender, B. A. and Coblenz, W. S., Am. Ceram. Soc. Bull., Vol. 62, pp. 916-923 (1983).

105) Paine, R. T., Janik, J. F. and Fan, M., Polyhedron, Vol. 13, pp. 1225-1232 (1994).

106) Seyferth, D., Bryson, N., Workman, D. P. and Sobon, C. A., J. Am. Ceram. Soc., Vol. 74, pp. 2687-2689 (1991) .

107) Greil, P., J. Am. Ceram. Soc., Vol. 78, pp. 835-848 (1995).

108) Su, K., Nowakowski, M., Bonnell, D. and Sneddon, L. G., Chem. Mater., Vol. 4, pp. 1139-1141 (1992).

109) Idesaki, A., Narisawa, M., Okamura, K., Sugimoto, M., Tanaka. S., Morita, Y., Seguchi, T. and Itoh, M., J. Mater. Sci., Vol. 36, pp. 5565-5569 (2001).

110) Czekaj, C. L., Hackney, M. L. J., Hurley, Jr., W. J., Interrante, L. V., Sigel, G. A., Shields, P. J. and Slack, G. A., J. Am. Ceram. Soc., Vol. 73, pp. 352-357 (1990).

111) Interrante, L. V., Schmidt, W. R., Marchetti, P. S. and Maciel, G. E., Mater. Res. Soc. Symp. Proc., Vol. 249, pp. 31-43 (1992).

112) Interrante, L. V., Hurley, Jr., W. J., Schmidt, W. R., Kwon, D., Doremus, R. H., Marchetti, P. S. and Maciel, G. E., Ceram. Trans., Vol. 19, pp. 3-17 (1991).

113) Schmidt, W. R., Hurley, Jr., W. J., Sukumar, V., Doremus, R. H. and Interrante, L. V., Mater. Res. Soc. Symp. Proc., Vol. 171, pp. 79-84 (1990).

114) Moraes, K., Vosburg, J., Wark, D., Interrante, L. V., Puerta, A. R., Sneddon, L. G. and Narisawa, M., Chem. Mater., Vol. 16, pp. 125-132 (2004).

115) Baldus, H.-P., Wagner, O. and Jansen, M., Mater. Res. Soc. Symp. Proc., Vol. 271, pp. 821-832 (1992).

116) Janik, J. F., Duesler, E. N. and Paine, R. T., Inorg. Chem., Vol. 26, pp. 4341-4345 (1987).

117) Janik, J. F., Duesler, E. N. and Paine, R. T., Inorg. Chem., Vol. 27, pp. 4335-4338 (1988).

118) Paciorek, K. J. L., Nakahara, J. H., Hoferkamp, L. A., George, C., Flippen-Anderson, J. L., Gilardi, R. and Schmidt, W. R., Chem. Mater., Vol. 3, pp. 82-87 (1991).

119) Löffelholz, J. and Jansen, M., Adv. Mater., Vol. 7, pp. 289-292 (1995).

120) Hapke, J. and Ziegler, G., Adv. Mater., Vol. 7, pp. 380-384 (1995).

121) Seyferth, D. and Plenio, H., J. Am. Ceram. Soc., Vol. 73, pp. 2131-2133 (1990).

122) Seyferth, D., Brodt, G. and Boury, B., J. Mater, Sci. Lett., Vol. 15, pp. 348-349 (1996).

123) Boury, B. and Seyferth, D., Appl. Organomet. Chem., Vol. 13, pp. 431-440 (1999).

124) Schmit, W. R., Hurley, Jr., W. J., Doremus, R. H., Inter- 
rante, L. V. and Marchetti, P. S., Ceram. Trans., Vol. 19, pp. 19-25 (1991).

125) Bill, J., Friess, M., Aldinger, F. and Riedel, R., Mater. Res. Soc. Symp. Proc., Vol. 346, pp. 605-610 (1994).

126) Reidel, R. and Dressler, W., Ceram. Int., Vol. 22, pp. 233-239 (1996).

127) Funayama, O., Kato, T., Tashiro, Y. and Isoda, T., J. Am. Ceram. Soc., Vol. 76, pp. 717-723 (1993).

128) Funayama, O., Tashiro, Y., Aoki, T. and Isoda, T., J. Ceram. Soc. Japan, Vol. 102, pp. 908-912 (1994).

129) Iwamoto, Y., Matsubara, H. and Brook, R. J., Ceram. Trans., Vol. 51, pp. 193-197 (1995).

130) Iwamoto, Y., Kikuta, K. and Hirano, S., J. Mater. Res., Vol. 13, pp. 353-361 (1998).

131) Iwamoto, Y., Kikuta, K. and Hirano, S., J. Ceram. Soc. Japan, Vol. 108, pp. 350-356 (2000).

132) Yajima, S., Iwai, T., Yamamura, T., Okamura, K. and Hasegawa, Y., J. Mater. Sci., Vol. 16, pp. 1349-1355 (1981).

133) Soraru, G. D., Ravagni, A., Campostrini, R. and Babonneau, F., J. Am. Ceram. Soc., Vol. 74, pp. 2220-2223 (1991).

134) Babonneau, F. and Soraru, G. D., J. Eur. Ceram. Soc., Vol. 8, pp. 29-34 (1991).

135) Su, K., Remsen, E. E., Zank, G. A. and Sneddon, L. G., Chem. Mater., Vol. 5, pp. 547-556 (1993).

136) Wideman, T., Su, K., Remsen, E. E., Zank, G. A. and Sneddon, L. G., Chem. Mater., Vol. 7, pp. 2203-2212 (1995).

137) Wideman, T., Cortez, E., Remsen, E. E., Zank, G. A., Carroll, P. J. and Sneddon, L. G., Chem. Mater., Vol. 9, pp. 2218-2230 (1997).

138) Riedel, R., Kienzle, A., Dressler, W., Ruwisch, L., Bill, J. and Aldinger, F., Nature, Vol. 382, pp. 796-798 (1996).

139) Riedel, R., Bill, J. and Kienzle, A., Appl. Organomet. Chem., Vol. 10, pp. 241-256 (1996).

140) Baldus, H.-P. and Jansen, M., Angew. Chem. Int. Ed. Engl., Vol. 36, pp. 329-343 (1997).

141) Schmidt, W. R., Interrante, L. V., Doremus, R. H., Trout, T. K., Marchetti, P. S. and Maciel, G. E., Chem. Mater., Vol. 3, pp. 257-267 (1991).

142) Maya, L., Adv. Ceram. Mater., Vol. 1, pp. 150-153 (1986).

143) Kwon, D., Schmidt, W. R., Interrante, L. V., Marchetti, P. and Maciel, G., "In Inorganic and Organometallic Oligomer and Polymers," Ed. by. Harrod, J. F. and Laine, R. M., Kluwer Academic Publisher, Boston, MA (1991) pp. 191-197.

144) Koyama, S., Nakashima, H., Sugahara, Y. and Kuroda, K., Chem. Lett., pp. 191-192 (1998).

145) Nakashima, H., Koyama, S., Kuroda, K. and Sugahara, Y., J. Am. Ceram. Soc., Vol. 85, pp. 59-64 (2002).

146) Cheng, F., Sugahara, Y. and Kuroda, K., Korean J. Ceram., Vol. 6, pp. 32-36 (2000).

147) Wiberg, E., "FIAT Review of German Science," Vol. 24, Inorganic Chemistry Pt. 2, Ed. by Klemm, W., Dieterichsche Verlagsbuchhandlung, Wiebaden (1948) pp. 155-179.

148) Sauls, F. C. and Interrante, L. V., Coord. Chem. Rev., Vol. 128, pp. 193-207 (1993).

149) Sauls, F. C., Interrante, L. V. and Jiang, Z., Inorg. Chem., Vol. 29, pp. 2989-2996 (1990).

150) Sauls, F. C., Czekaj, C. L. and Interrante, L. V., Inorg. Chem., Vol. 29, pp. 4688-4692 (1990).

151) Sauls, F. C., Hurley, Jr., W. J., Interrante, L. V., Marchetti, P. S. and Maciel, G. E., Chem. Mater., Vol. 7, pp. 1361-1368 (1995).

152) Baker, R. T., Bolt, J. D., Reddy, G. S., Roe, D. C., Staley, R. H., Tebbe, F. N. and Vega, A. J., Mater. Res. Soc. Symp. Proc., Vol. 121, pp. 471-476 (1988).

153) Tebbe, F. N., Bolt, J. D., Young, Jr., R. J., Buskirk, O. R. V., Mahler, W., Reddy, G. S. and Chowdhry, U., Adv. Ceram., Vol. 26, pp. 63-68 (1989).

154) Bolt, J. D. and Tebbe, F. N., Adv. Ceram., Vol. 26, pp. 69-76 (1989).

155) Bolt, J. D. and Tebbe, F. N., Mater. Res. Soc. Symp. Proc., Vol. 108, pp. 337-344 (1988).
156) Jiang, Z., Interrante, L. V., Kwon, D., Tham, F. S. and Kullnig, R., Inorg. Chem., Vol. 30, pp. 995-1000 (1991).

157) Jiang, Z. and Interrante, L. V., Chem. Mater., Vol. 2, pp. 439-446 (1990).

158) Jiang, Z., Interrante, L. V., Kwon, D., Tham, F. S. and Kullnig, R., Inorg. Chem., Vol. 31, pp. 4815-4822 (1992).

159) Jensen, J. A., Mater. Res. Soc. Symp. Proc., Vol. 271, pp. 845-850 (1992).

160) Jansen, J. A., "Inorganic and Organometallic Polymers II;" in ACS Symposium Series, Vol. 572, Ed. by Wisian-Neilson, P., Allcock, H. R. and Wynne, K. J., American Chemical Society, Washington, D. C. (1994) pp. 427-439.

161) Wiberg, E. and May, A., Z. Naturforsch., Vol. 10B, pp. 229-232 (1955).

162) Ochi, A., Bowen, H. K. and Rhine, W., Mater. Res. Soc. Symp. Proc., Vol. 121, pp. 663-666 (1988).

163) Rockensüß, W. and Roesky, H. W., Adv. Mater., Vol. 5, pp. 443-445 (1993).

164) Janik, J. F. and Paine, R. T., J. Organomet. Chem., Vol. 449, pp. 39-44 (1993).

165) Coffman, P. R., Petuskey, W. T. and Dey, S. K., Mater. Res. Soc. Symp. Proc., Vol. 180, pp. 709-714 (1990).

166) Schmidbaur, H. and Schmidt, M., Angew. Chem., Vol. 74, pp. 327-327 (1962).

167) Wiberg, N. and Schmid, K.-H., Z. Anorg. Allg. Chem., Vol. 345, pp. 93-105 (1966).

168) Schleich, D. M., US Patent 4767607 (1988).

169) Riedel, R., Petzow, G. and Klingebiel, U., J. Mater, Sci. Lett., Vol. 9, pp. 222-224 (1990).

170) Hyodo, T., Kano, M., Shimizu, Y. and Egashira, M., J. Ceram. Soc. Japan, Vol. 109, pp. 709-711 (2001).

171) Cesari, M. and Cucinella, S., "Aluminum-Nitrogen Ring and Cages;" in The Chemistry of Inorganic Homo- and Heterocycles, Ed. by Sowerby, D. B. and Haiduc, I., Academic Press, London, UK (1987) pp. 167-190.

172) Timoshkin, A. Y. and Schaefer, III, H. F., Chem. Rec., Vol. 2, pp. 319-338 (2002).

173) Timoshkin, A. Y., Cood. Chem. Rev., Vol. 249, pp. 2049-2131 (2005).

174) Cheng, F., Clark, S., Archibald, S. J., Kelly, S. M. and Bradley, J. S., J. Organomet. Chem., Vol. 690, pp. 1205-1208 (2005).

175) Sugahara, Y., Onuma, T., Tanegashima, O., Kuroda, K. and Kato, C., J. Ceram. Soc. Japan, Vol. 100, pp. 101-103 (1992).

176) Saito, Y., Koyama, S., Sugahara, Y. and Kuroda, K., J. Ceram. Soc. Japan, Vol. 104, pp. 143-145 (1996).

177) Sugahara, Y., Koyama, S. and Kuroda, K., Key Eng. Mater., Vol. 159-160, pp. 77-82 (1999).

178) Saito, Y., Sugahara, Y. and Kuroda, K., J. Am. Ceram. Soc., Vol. 83, pp. 2436-2440 (2000).

179) Koyama, S., Takeda, H., Saito, Y., Sugahara, Y. and Kuroda, K., J. Mater. Chem., Vol. 6, pp. 1055-1058 (1996).

180) Koyama, S., Takeda, H., Tsugoshi, T., Watari, K. and Sugahara, Y., J. Ceram. Soc. Japan, Vol. 114, pp. 563-566 (2006).

181) Mori, Y., Kumakura, Y. and Sugahara, Y., J. Organomet. Chem., submitted.

182) Koyama, S., Saito, Y., Sugahara, Y. and Kuroda, K., Chem. Lett., pp. 1227-1228 (1997).

183) Interrante, L. V., Lee, W., McConnell, M., Lewis, N. and Hall, E., J. Electrochem. Soc., Vol. 136, pp. 472-478 (1989).

184) Amato, C. C., Hudson, J. B. and Interrante, L.V., Mater. Res. Soc. Symp. Proc., Vol. 168, pp. 119-124 (1990).

185) Amato, C. C., Hudson, J. B. and Interrante, L.V., Appl. Surf. Sci., Vol. 54, pp. 18-24 (1992).

186) Seibold, M. M. and Rüssel, C., J. Am. Ceram. Soc., Vol. 72, pp. 1503-1505 (1989).

187) Seibold, M. M. and Rüssel, C., Mater. Res. Soc. Symp. Proc., Vol. 121, pp. 477-482 (1988).

188) Teusel, I. and Rüssel, C., J. Mater. Sci., Vol. 25, pp. 
3531-3534 (1990).

189) Distler, P. and Rüssel, C., J. Mater. Sci., Vol. 27, pp. 133-138 (1992).

190) Geyer, V. and Rüssel, C., J. Non-Cryst. Solids, Vol. 149, pp. 196-202 (1992).

191） Ross, C. B., Wade, T. and Crooks, R. M., Chem. Mater., Vol. 3, pp. 768-771 (1991).

192) Wade, T., Park, J., Garza, E. G., Ross, C. B., Smith, D. M. and Crooks, R. M., J. Am. Chem. Soc., Vol. 114, pp. 9457-9464 (1992).

193) Wade, T., Park, J., Garza, E. G., Ross, C. B., Smith, D. M. and Crooks, R. M., Mater. Res. Soc. Symp. Proc., Vol. 271, pp. 857-868 (1992).

194) Shimada, S. and Hayashi, S., Mater. Sci. Eng., B, Vol. B122, pp. 34-40 (2005). 